\title{
Status and Conservation of the Japanese Murrelet (Synthliboramphus wumizusume) in the Izu Islands, Japan
}

\author{
Harry R. Carter ${ }^{1}$, Koji Ono ${ }^{2}$, John N. Fries ${ }^{3}$, Hiroshi Hasegawa ${ }^{4}$, \\ Mutsuyuki Ueta ${ }^{5}$, Hiroyoshi Higuchi ${ }^{6}$, Jack T. Moyer ${ }^{7}$, \\ Leigh K. Ochikubo Chan ${ }^{8}$, Leah N. de Forest ${ }^{9}$, \\ Masami Hasegawa ${ }^{10}$ and Gustaaf B. van Vliet $^{11}$
}

\begin{abstract}
We collated available evidence of breeding and conservation problems for the Japanese Murrelet in the Izu Islands, Japan. After species description in 1835, it was first collected in the Izu Islands in 1877, with breeding first noted in 1901. Over the 20th century, murrelets were found breeding at 11 islands (i.e., Udonejima, Niijima, Shikinejima, Hanshima, Kozushima, Onbasejima, Tadanaejima, Sanbondake, Motone, Kojine, and Torishima) and were not thought to breed at 7 islands (i.e., Oshima, Toshima, Jinaijima, Miyakejima, Mikurajima, Hachijojima, and Hachijokojima). Surveys have not been conducted at 7 islands (i.e., Zenisu, Inanbajima, Aogashima, Beyoneizu-Retsugan, Myojinsho, Sumisujima, and Sofugan). The population is centered in the northern Izu Islands between Udonejima and Sanbondake. Once considered the world stronghold for the species, a large population decline apparently occurred in the mid-late 20th century: a) breeding no longer occurs at Shikinejima and Kozushima; b) some breeding habitat has been lost at Sanbondake; c) large numbers of nests reported by egg harvesters at Udonejima, Hanshima, and Sanbondake in early century no longer occur; and d) murrelets were observed less frequently on ferry trips between Oshima and Niijima in 1990-95 than in 1983-89. Current breeding population size appears to range between $350-850$ breeding pairs ( $~ 7-43 \%$ of the global population estimated between 4,000-10,000 birds or 2,0005,000 pairs). Major colonies occur at Tadanaejima (100-300 pairs), Onbasejima (75-150 pairs), and Sanbondake (75-100 pairs), plus 20-30 pairs at Kojine. Another 100-300 pairs
\end{abstract}

Received 31 March 2001, Revised 25 October 2001, Accepted 12 December 2001.

Paper presented in a symposium held by the Japanese Seabird Group and Pacific Seabird Group (Lihue, Hawaii; February 2001).

${ }^{1}$ Humboldt State University, Department of Wildlife, Arcata, CA 95521 USA (Send correspondence: c/o U.S. Geological Survey, 6924 Tremont Road, Dixon, CA 95620 USA).

${ }^{2}$ Hokkaido Seabird Center, Kita 6-1, Haboro, Tomamae 078-4116 Japan.

3 University of California, Graduate Group in Ecology, Davis, CA 95616 USA.

4 Toho University, Laboratory of Marine Biology, Faculty of Science, 2-2-1 Miyama, Funabashi-shi, Chiba 274-8510 Japan.

${ }^{5}$ Wild Bird Society of Japan, Research Center, Minamidaira 2-35-2, Hino, Tokyo 191-0041 Japan.

${ }^{6}$ University of Tokyo, Laboratory of Biodiversity Sciences, School of Agriculture and Life Sciences, 1-1-1 Yayoi, Bunkyo-ku, Tokyo 113-8657 Japan.

${ }^{7}$ Miyakejima Nature Center (Akakokko-kan), 4188 Tsubota, Miyake-mura, Miyakejima, Tokyo 100-1211 Japan.

${ }^{8}$ East Bay Municipal Utility District, 1 Winemasters Way, Lodi, CA 95240 USA.

${ }^{9}$ Parks Canada, 25 Eddy Street, Hull, Quebec K1A 0M5 Canada.

10 Toho University, Laboratory of Geographical Ecology, Faculty of Science, 2-2-1 Miyama, Funabashi-shi, Chiba 274-8510 Japan.

1 P.O. Box 210442, Auke Bay, AK 99821 USA. 
may nest at other islands (i.e., Udonejima, Niijima, Hanshima, and Torishima) where recent estimates are not available. Conservation issues include: human settlement; past egg harvesting; recreational surf fishing at remote islands; predation by introduced predators; habitat loss due to post-war bombing of Sanbondake; habitat destruction due to human activities; habitat loss due to volcanic eruptions; relatively high levels of predation by crows, snakes, and falcons; and mortality in commercial gill nets. Additional surveys, monitoring, and assessment of conservation issues are urgently needed in Izu Islands for this rarest species of the family Alcidae which is endemic to Japan.

Key words: Japanese Murrelet, Izu Islands, Breeding status, Conservation issues, Predation by introduced predators, Gill net fishery.

キーワード：カンムリウミスズメ，伊豆諸島，繁殖現状，保全上の問題, 移入動 物による捕食, 刺し網漁業.

\section{Introduction}

The Japanese Murrelet (Synthliboramphus wumizusume; see frontispiece) is the rarest alcid in the world with a global population of about 4,000-10,000 birds and a highly restricted nesting distribution endemic to southern Japan, with one known colony in southern Korea (Ono 1993a 1996, Springer et al. 1993, Gaston \& Jones 1998, OSJ 2000). This species was first described by Temminck in 1835 (Yamaguchi 1984) and was referred to as "Temminck's Guillemot" in the late 19th century. In the past, it was erroneously thought to range across the North Pacific from Japan to Washington state, USA (e.g., Baird et al. 1884). By the mid 20th century, Austin \& Kuroda (1953) recognized that the Izu Islands, south of Tokyo, hosted the largest known population of the species in the world, although nesting also was known off Kyushu, and: "It is nowhere plentiful, even on its little-known breeding grounds, and is steadily becoming scarcer". By the late 20th century, the known breeding distribution included islands along the Honshu coast of the Japan Sea, greater numbers were known to occur at more Kyushu colonies, and colonies in the Izu Islands were thought to have declined further (Higuchi 1979, Brazil 1991, Ono 1993a, 1996). In 1972, the species was designated as a "national monument" because of its high scientific value as an endemic species that deserved or needed preservation.

The Izu Islands are volcanic in origin and consist of 25 islands that extend in a chain about $450 \mathrm{~km}$ south from the southeastern shore of Honshu near Tokyo (Fig. 1). We consider these islands to fall into three major sections: a) northern section (Oshima to Inanbajima; $\mathrm{n}=16$ islands); $\mathrm{b}$ ) central section (Hachijojima to Sumisujima; $\mathbf{n}=\mathbf{7}$ islands); and c) southern section (Torishima and Sofugan; $n=2$ islands) (see Fig. 1). We have defined "island groups" where larger islands have smaller satellite islands, as follows: a) Toshima with satellite Udonejima; b) Niijima with satellites Jinaijima, Shikinejima, and Hanshima; c) Kozushima with satellites Onbasejima and Tadanaejima; d) Miyakejima with satellite Sanbondake; e) Mikurajima with satellite Motone; and f) Hachijojima with satellites Hachijokojima and Kojine. Some other islands occur singly (i.e., Oshima, Zenisu, Inanbajima, Aogashima, Sumisujima, Torishima, and Sofugan). Two small islands also form a group (Beyoneizu-Retsugan and Myojinsho). The Izu Islands are bathed in the warm temperate water of the Kuroshio Current between about $30-35^{\circ} \mathrm{N}$ 


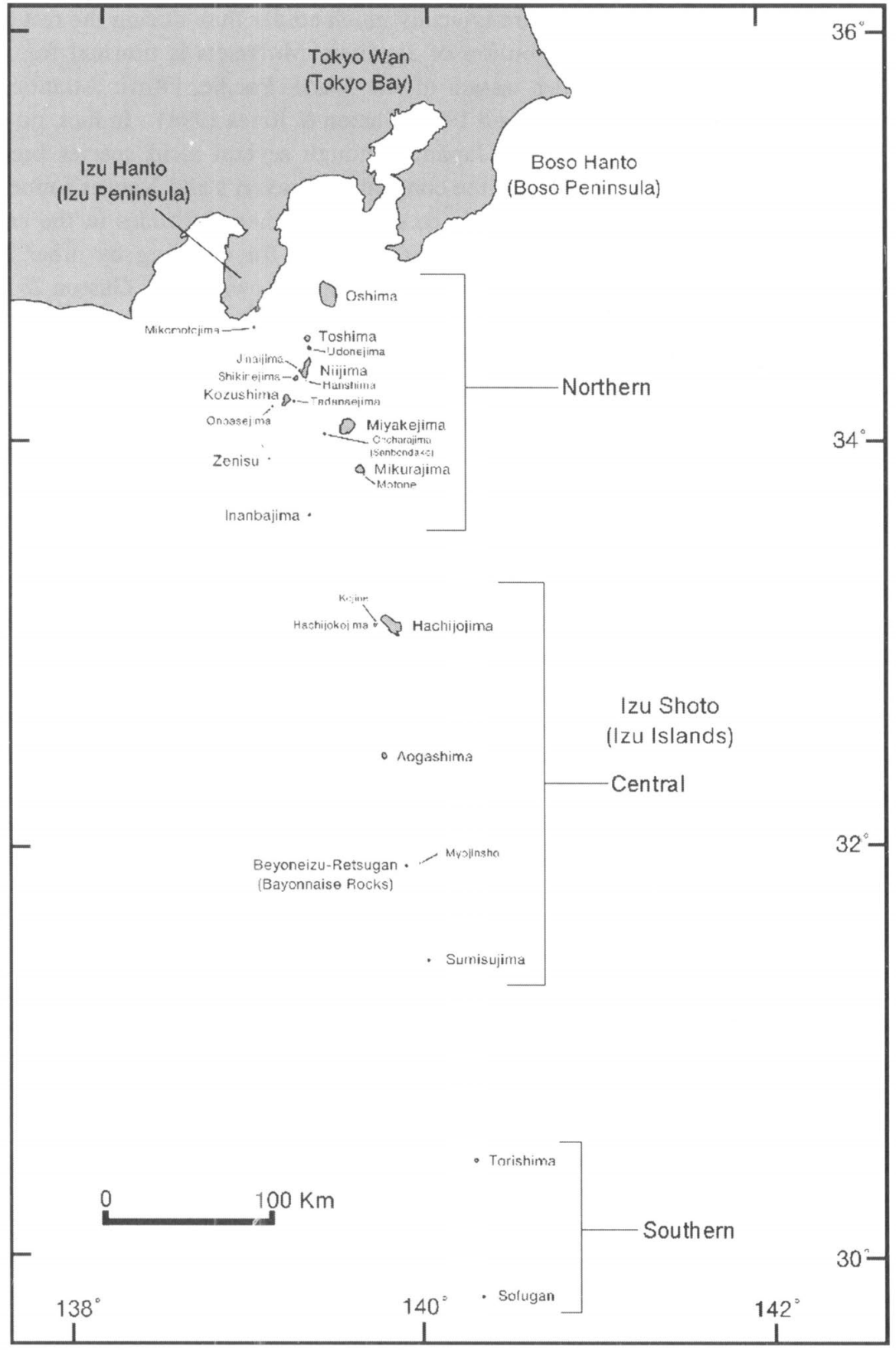

Fig. 1. Map of the Izu Islands, Japan, with northern, central and southern sections indicated. 
(Fig. 1). However, in spring, waters are typically much colder than during the rest of the year. This southern breeding distribution of Japanese Murrelets is unusual for alcids which occur primarily in the colder waters of the North Pacific, North Atlantic, and Arctic oceans (e.g., Nettleship \& Birkhead 1985, Gaston \& Jones 1998). In fact, no other alcids breed in the southern waters of Japan, although several alcid species breed in northern Japan (Brazil 1991). However, the congeneric Craveri's and Xantus's murrelets (S. craveri, S. hypoleucus) also are endemic to similar southern latitudes in the eastern Pacific Ocean, and much of this region also is not used for breeding by other alcids (Springer et al. 1993, Takekawa \& Carter 1994, Drost \& Lewis 1995, Gaston \& Jones 1998).

In the 1980s and 1990s, several expeditions were made to the Izu Islands by Japanese and North American biologists to obtain updated information on the status of several murrelet colonies (WBSJ 1993, 1994, Carter \& de Forest 1993, 1994a,b, Carter et al. 1994, Higuchi 1994, Moyer 1994, H. Hasegawa, unpubl. data). However, despite many efforts, strong spring winds in the Izu Islands have prevented frequent visitation of known nesting islands and many isolated islands have yet to be surveyed. Along with the difficulty of finding murrelet nests and estimating breeding population size, a detailed assessment of population trends still has not been conducted to date. In addition, historical data on the status of the Japanese Murrelet and information on conservation problems in the Izu Islands is widely scattered and has never been fully collated. However, partial summaries are available and have provided a strong foundation to build upon to assess the status of the species in the Izu Islands (Higuchi 1979, Ono 1993a, 1996). In this paper, we attempt to collate all available information on Japanese Murrelets in the Izu Islands to provide the most complete summary to date on population status and conservation problems. This collation contributes to on-going efforts to survey, study and protect the Japanese Murrelet and to develop a catalog of Japanese seabird colonies in the past and present.

\section{Methods}

By collating Japanese, American, and other sources, we provided a brief summary of all available published and unpublished information on Japanese Murrelets in the Izu islands, Japan. We focused mainly on available publications, unpublished reports, unpublished correspondence, and museum specimens of adults and eggs. Abbreviations for museums mentioned in the text can be found in the acknowledgments section. We consider that this summary is largely complete but recognize that we have not uncovered all unpublished information nor all specimens that may exist in museums or private collections around the world. Greater detail is provided for unpublished information since published sources can be consulted for more information. Information is presented chronologically for each of the 25 islands in approximate north to south order within the Izu Islands chain (see Fig. 1; Table 1). This summary is followed by an overall synthesis of population status and conservation problems of the Japanese Murrelet in the Izu Islands. 
Table 1. Summary of breeding status for Japanese Murrelets in the Izu Islands, Japan. Islands are listed in north to south order.

\begin{tabular}{|c|c|c|}
\hline Island & Status $^{1}$ & No. breeding pairs ${ }^{2}$ \\
\hline \multicolumn{3}{|l|}{ Northern Section } \\
\hline OSHIMA & $\mathrm{PB}$ & None known \\
\hline TOSHIMA & PB & None known \\
\hline Udonejima & B & Small numbers $(\sim 50-100$ pairs $)$ \\
\hline NIIJIMA & B & Small numbers $(\sim 10-25$ pairs $)$ \\
\hline Jinaijima & PB & None known \\
\hline Shikinejima & HB & Historical only \\
\hline Hanshima & B & Small numbers ( $\sim 25-50$ pairs $)$ \\
\hline KOZUSHIMA & HB & Historical only \\
\hline Onbasejima & B & $75-150$ pairs \\
\hline Tadanaejima & B & $100-300$ pairs \\
\hline ZENISU & NS & Unknown \\
\hline MIYAKEJIMA & NH & None known \\
\hline Sanbondake & B & 75-100 pairs \\
\hline MIKURAJIMA & PB & None known \\
\hline Motone & B & Small numbers $(\sim 10-25$ pairs $)$ \\
\hline INANBAJIMA & NS & Unknown \\
\hline \multicolumn{3}{|l|}{ Central Section } \\
\hline HACHIJOJIMA & NH & None known \\
\hline Hachijokojima & NH & None known \\
\hline Kojine & B & 20-30 pairs \\
\hline AOGASHIMA & NS & Unknown \\
\hline BEYONEIZU-RETSUGAN & NS & Unknown \\
\hline MYOJINSHO & NS & Unknown \\
\hline SUMISUJIMA & NS & Unknown \\
\hline \multicolumn{3}{|l|}{ Southern Section } \\
\hline TORISHIMA & B & Small numbers $(\sim 10-25$ pairs $)$ \\
\hline SOFUGAN & NS & Unknown \\
\hline \multicolumn{3}{|l|}{ Subtotal } \\
\hline Recent estimates & & $\sim 270-580$ pairs \\
\hline No recent estimates & & $\sim 105-225$ pairs \\
\hline Total & & $\sim 350-850$ pairs \\
\hline
\end{tabular}

${ }^{1}$ Status Codes: B, breeding confirmed; HB, historical breeding; PB, possible breeding; NH, no habitat, and NS, no surveys.

2 Parentheses around numbers indicate no recent estimates are available and very rough estimates are based on apparent suitable habitat relative to colonies with recent estimates.

\section{Results}

\section{Northern Section of the Izu Islands}

OSHIMA: This large, heavily-populated, island (9,098 hectares) surrounds a large volcanic cone (Mihara Mountain, $758 \mathrm{~m}$; last active in 1986) and does not have satellite 
islands. No murrelet nesting areas have been described and much of the coastal areas are low lying or built upon but current breeding may occur in inaccessible cliffs and steep slope areas. Momiyama (1923) noted that Japanese Murrelets were commonly observed on the water off Oshima in winter. Kiyosu (1952) listed Oshima as breeding grounds but evidence of breeding has not been obtained, although murrelets are known to feed at sea near Oshima during the breeding season. The only specimen record is an adult collected on 16 May 1947 at Oshima by O. L. Austin, Jr. (USNM \#276928). In addition, murrelets are known to breed at nearby Mikomotojima off the Izu Peninsula (Fig. 1; Brazil 1991, Ono 1993a, 1996) and murrelets from this and other Izu colonies (especially Udonejima) may occur at sea near Oshima. Japanese Murrelets were counted from a regularlyscheduled ferry route between Oshima and Toshima from late March to early June 198295 (Mochizuki \& Ueta 1996). Murrelets were observed on more trips in 1983-89 (i.e., $46.7 \%$ of 15 counts) than in $1990-95$ (i.e., $6.9 \%$ of 29 counts), suggesting a population decline or much reduced foraging in this area.

TOSHIMA: This island is moderate-sized (419 hectares), surrounds a volcanic cone (Miyazuka Mountain), is populated on the north side only, and has Udonejima as a satellite. No murrelet nesting areas have been described and coastal areas are mainly low lying but current breeding may occur in inaccessible cliffs and steep slope areas. No records are available and evidence of breeding has not been obtained, although murrelets are known to feed at sea near Toshima during the breeding season. Murrelets were observed on more ferry trips between Toshima and Niijima (i.e., off Udonejima) in 198389 (i.e., $50 \%$ of 16 counts) than in 1990-95 (i.e., $18.5 \%$ of 27 counts), suggesting a population decline or much reduced foraging in this area (Mochizuki \& Ueta 1996).

Udonejima: This small uninhabited island off Toshima is largely covered with grasses, has a dwarfed forest around the summit, and appears to have abundant suitable nesting habitat for murrelets. Murrelets likely nest in rock crevices but nests have not been well described. Yamashina (1936) reported breeding, based on "hearsay information", on small islands near "Une Island" which seemed to Higuchi (1979) to refer to Udonejima. Kiyosu (1952, 1965), OSJ (1974), and Brazil (1991) list Udonejima as breeding grounds, without details. Moyer (1994) recalled visiting Udonejima in the 1950s but could not recall if evidence of nesting by murrelets was found (J. T. Moyer, pers. comm.). WBSJ (1993) conducted a fishing-boat survey around Udonejima on 27 April 1992 (17:50-18: 10) and 28 April 1992 (04:10-06:05) but no murrelets were observed. However, Ochikubo (1995) reported about 30 murrelets at sea from a fishing boat near Udonejima at night on the early morning of 28 April 1995 and one murrelet was captured onboard that was likely attracted by boat lights. Fishermen also reported that they had harvested murrelet eggs (about 10-15 nests per day, twice per year) for consumption at Udonejima in the 1950s. Streaked Shearwaters Calonectris leucomelas also are known to nest at Udonejima (Hasegawa 1984; Brazil 1991), indicating suitable nesting conditions for seabirds and low human disturbance.

NIIJIMA: This medium-sized, heavily-populated, island (2,284 hectares) surrounds 
several volcanic cones (Miyatsuka, Mukai, Acchi Aomine mountains) with largely low-lying coastal areas and some exposed volcanic-ash cliffs. It has three satellite islands: Jinaijima, Shikinejima, and Hanshima. Murrelet nesting has been described mainly in rock piles below cliffs at Cape Neuki but murrelets also may nest in other inaccessible cliffs and steep slopes. A clutch of two eggs was collected in the "first half" of May 1930 at "Miyakejima, Niijima" (KC \#1676). This confusing specimen location may reflect Niijima on the way to Miyakejima because other murrelet eggs in the same collection were collected at Sanbondake specifically on 10 May 1930 (see below). The only adult specimen record was collected at Niijima on 5 May 1947 by O. L. Austin, Jr. (USNM \#276100). Murrelets are known to feed at sea near Niijima during the breeding season.

In the 1980s, breeding was reported on Cape Nebu (Isobe 1982, 1990). One nest was apparently found but this record was not fully substantiated (H. Higuchi, pers. comm.). WBSJ (1993) conducted a fishing-boat survey on 28 April 1992 (03:40-04:10) near Cape Nebu: 37 murrelets were observed and murrelets were heard vocalizing from land at night. On 14 April 1994, Carter et al. (1994) reported 3 murrelets at sea (16:00) from a ferry traveling off the east side of Niijima between Miyakejima and Tokyo. Ochikubo (1995) reported a pair of murrelets at sea just north of Cape Nebu on 28 April 1995. Fishermen also reported that they had harvested murrelet eggs (roughly about 100-200 nests were harvested per day by 4-5 people on two harvesting trips per year) for consumption at Cape Nebu in the 1950s. Such egg harvesting was thought to have occurred since the early 19 th century but stopped by about 1955. Murrelets were observed only once on 31 ferry counts between Niijima and Shikinejima in 1986-95, indicating little foraging off the west side of Niijima (Mochizuki \& Ueta 1996).

Jinaijima: This small unpopulated island off Niijima is vegetated and visited regularly by humans. No murrelet nesting habitats have been described. Ochikubo (1995) conducted a nest search on 6 May 1995: suitable nesting habitat existed but no evidence of nesting was found. Rabbits and probably cats likely occur on the island. Past nesting may have occurred without documentation. WBSJ (1993) conducted a fishing-boat survey around Jinaijima on 28 April 1992 (09:40-10:10) but no murrelets were observed.

Hanshima: This small unpopulated rock off Niijima has little or no vegetation and murrelets appear to nest in rock crevices. In April 1986, H. Hasegawa found nests of Japanese Murrelets at Hanshima (H. Hasegawa, unpubl. data). WBSJ (1993) conducted a fishing-boat survey around Hanshima on 28 April 1992 (07:00-07:45) but no murrelets were observed. On 27 April 1995, 11 birds (probably Japanese Murrelets) were counted flying near Hanshima at dusk (Ochikubo 1995). Ochikubo (1995) also reported that fishermen reported nesting in the 1940s or 1950s at Hanshima, presumably during egg harvesting for consumption.

Shikinejima: This small island is vegetated, populated (once a penal colony), and surrounded by low-lying $(10-30 \mathrm{~m})$ cliffs. It reaches an elevation of $99 \mathrm{~m}$ at Kanbiki Mountain which occurs close to the coast at the west end of the island. Breeding has been reported at Shikinejima by several sources without details (Yamashina 1936, OSJ 1942, Kiyosu 1952, Austin \& Kuroda 1953, OSJ 1974, Brazil 1991). Hasegawa (1984) also reported nesting at Shikinejima "but current status on these islands is unknown". On 12 
April 1936, 5 clutches were collected at "southern cliff of Shikinejima" (YIO \#85-1317 to 85-1320, 85-1322). Ochikubo (1995) reported that J. T. Moyer (pers. comm.) had found nests on the west side of Shikinejima in the 1950s at Kanbiki and at an area near Motokata. Based on available specimens, at least three specimens of adults (UMMZ $\# 154573,154574,154575$ ) and four clutches of eggs (UMMZ \#191197 to 191200) were collected at Kanbiki by J. T. Moyer on 26-27 April 1958.

Recent evidence of nesting has not been obtained and no murrelets have been observed near Shikinejima from ferries in 1986-95 (Mochizuki \& Ueta 1996). Ochikubo (1995) searched historical nesting habitats and stayed overnight to listen for calling murrelets at Kanbiki on 3 May 1995 (Fig. 2a), as well as searching other potential nesting habitats east of Nobushi Port on the northeast side of the island on 7 May 1995. No evidence of current nesting was found at historical nesting habitats but it is possible that very small numbers may still nest at Shikinejima in other inaccessible habitats that were not searched.

KOZUSHIMA: This large, heavily-populated, island (1,837 hectares) surrounds a large volcanic cone (Tenjou Mountain, $574 \mathrm{~m}$ ) and has two satellite islands (Onbasejima and Tadanaejima). Murrelet nesting areas have been described only on the south side of Kozushima but murrelets may nest in inaccessible cliffs and steep slopes at several areas around the island. It is not clear if early records for Kozushima refer to the main island or its satellite islands. Namie (1889) recorded breeding on the Kozushima, based on eggs and adult murrelets without details. This is the earliest mention in the literature of breeding by Japanese Murrelets in the Izu Islands. The only known specimens prior to 1889 were three adults collected at "Kozushima" on 28 April 1887 (USNM \#111653; YIO \#A972, A973) but it is unclear if these murrelets were collected at sea or at a colony. On 12 May 1901, at least six clutches of eggs were collected "for A. Owston" at Kozushima (BM \#1914.10.5.1, 1914.10.5.2, 1973.1.5 to 1973.1.8). In addition, an adult was collected on the same date at "Kozu=Kamidzu, Schito group, Seven Islands, near Hondo", presumably when the above eggs were collected (AMNH \#748202). On 12 May 1909, a set of two eggs were collected at "Kozushima" (NMBE \#1040581). Two other Kozushima clutches were in the Jourdain collection, one from 15 May 1919 (year unclear; BM \#1973.1.9) and the other undated (BM \#1973.1.1339).

Kiyosu (1952), OSJ (1974), and Brazil (1991) listed Kozushima as breeding grounds without details. Austin \& Kuroda (1953) reported nesting in the past at Kozushima. Hasegawa (1984) reported nesting at Kozushima "but current status on these islands is unknown". Carter et al. (1994) noted that a fisherman reported harvesting eggs for consumption on the south side of Kozushima, west of the east harbor, in 1960-65. A search of accessible nearby areas on 9 April 1994 did not find any evidence of nesting but some potential nesting habitat was present (Fig. 2b). Despite poor evidence of nesting on the main island of Kozushima, some nesting does appear to have occurred there. Between 1986 and 1995, small numbers of murrelets (maximum 15) were observed on 29 ferry trips between Shikinejima and Kozushima, indicating little foraging off the northwest side of Kozushima (Mochizuki \& Ueta 1996). On 28 April 1993, 15 murrelets were seen from a 

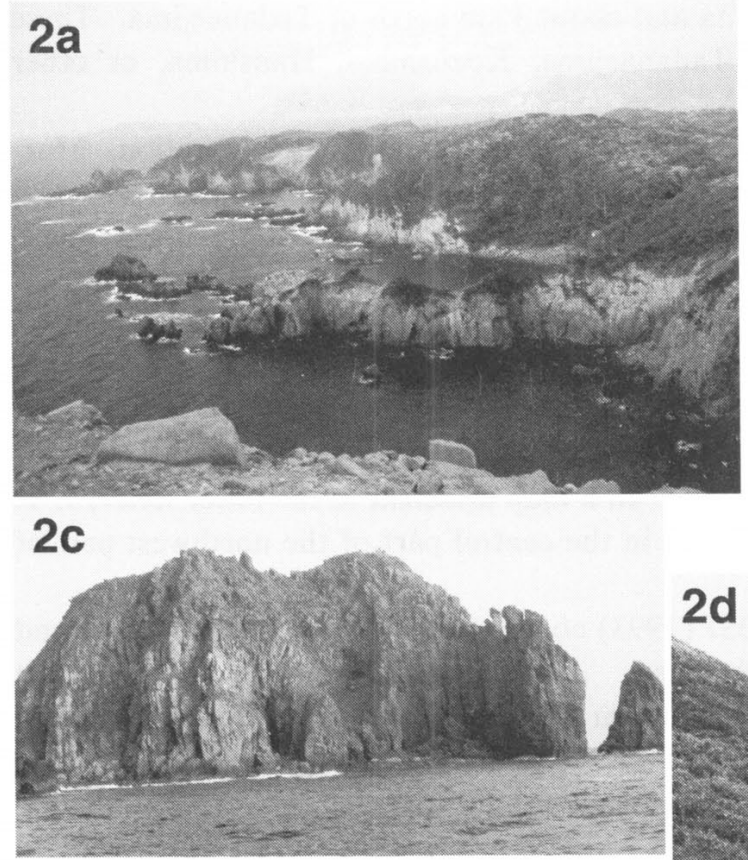

\section{$2 e$}
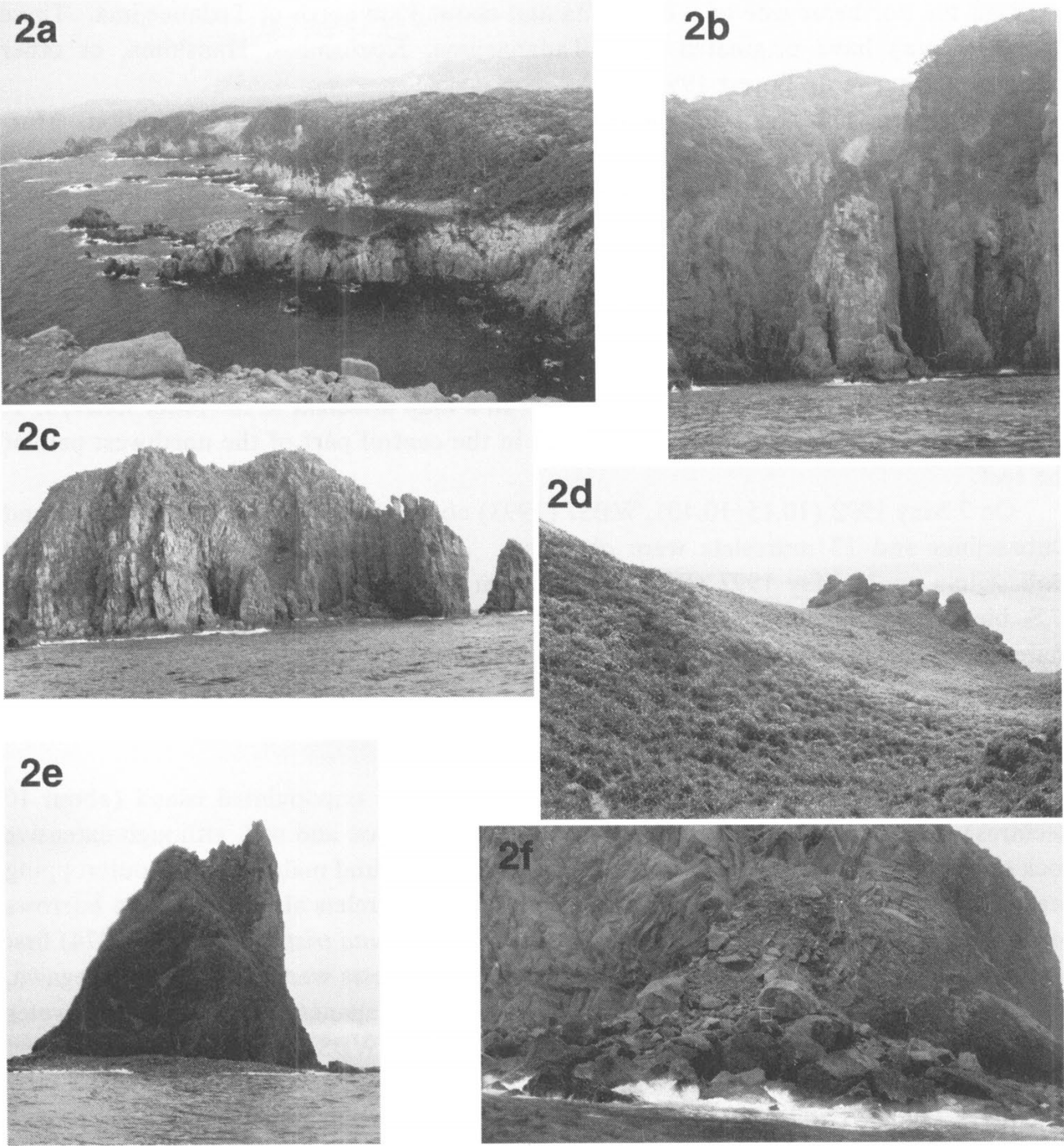

$2 d$
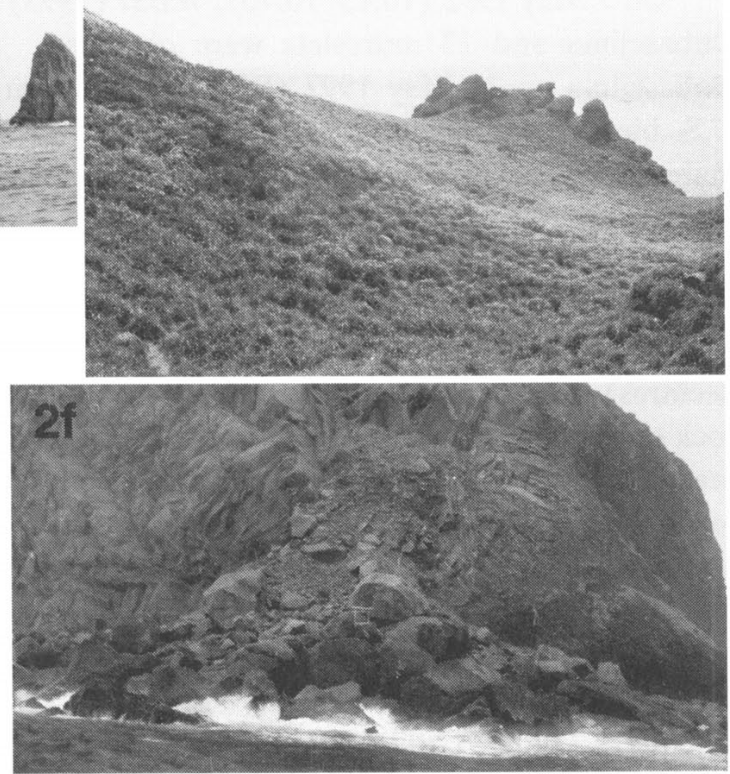

Fig. 2. Nesting habitats of Japanese Murrelets in the Izu islands: a) Kanbiki area of Shikinejima, 3 May 1995 (photo by L. K. Ochikubo Chan); b) South side of Kozushima, 28 April 1993 (photo by H. R. Carter); c) Northeast rock of Onbasejima, with east entrance to central arch visible midway up the slope in center, 28 April 1993 (photo by H. R. Carter); d) Tadanaejima, with rock outcropping, where several nests were found in 1992-95, and grassy slopes, 24 April 1993 (photo by H. R. Carter); e) Sanbondake, with bifurcated top from post-war bombing, 17 April 1995 (photo by L. K. Ochikubo Chan); and f) Sanbondake, with boulder pile where many nests were found in 1950s and 1990s, 17 April 1995 (photo by L. K. Ochikubo Chan). 
ferry off the northeast side of Kozushima and about $3 \mathrm{~km}$ north of Tadanaejima. These murrelets may have originated from Tadanaejima, Kozushima, Hanshima, or other colonies (Carter \& de Forest 1994a).

Onbasejima: This small unpopulated rock off Kozushima has little vegetation. Murrelets have been found nesting on the northwest side and the central arch of the north rock but also may nest in other inaccessible areas on the north and possibly south rocks. Yamashina (1936) reported breeding on small islands near Kozushima, based on "hearsay information", and this note may refer to Onbasejima or Tadanaejima. J. T. Moyer (21 April 1958 unpubl. correspondence to R. W. Storer, UMMZ) reported finding 29 nests in an hour and a half on 16 April 1958 at Onbasejima. In a 24 April 1958 letter to R. W. Storer (UMMZ), J. T. Moyer stated that "murrelets nest all over the reef, but each nest has to be searched for. They're well hidden." In a map attached to the latter letter, J. T. Moyer noted that murrelet nests were found in the central part of the northwest part of the reef.

On 7 May 1992 (10:15-10:40), WBSJ (1993) conducted a fishing-boat survey around Onbasejima and 13 murrelets were observed. A broken eggshell also was found at Onbasejima on 21 May 1992 (WBSJ 1994). On 8 April 1994, a team of Japanese and U.S. biologists conducted a complete search of accessible habitats of the northern reef, including the central arch area (Fig. 2c). Evidence for nine nest sites was found, including 6 active nests and 3 failed nests (one with a whole egg outside a crevice and two with broken eggshells)(Carter et al. 1994). Other broken eggshells were found away from nest sites. A rough estimate of 75-150 pairs was determined.

Tadanaejima (alternate name Hebijima): This small unpopulated island (about 10 hectares) off Kozushima is mainly covered in Elymus grass and soil, although extensive rock outcroppings also occur. Murrelet nests have been found mainly in rock outcropping areas but some have been found in grass tunnels and murrelets also may nest in burrows of the large colony of Tristram's Storm-Petrels (Oceanodroma tristrami). OSJ (1974) first noted potential breeding on Tadanaejima. In 1985-86, nests were found (H. Hasegawa, unpubl. data). K. Ono (unpublished data) recorded 110 Japanese Murrelets on the water in a $70^{\circ}$ count by spotting scope on 10 May 1991. In 1992, WBSJ (1993) reported one nest found at Tadanaejima. A fishing boat survey also was conducted around the island on 7 May 1992 (11:35-12:09) and 17 murrelets were observed. On 24-27 April 1993, a team of Japanese, U.S., and Canadian biologists conducted a detailed search of all rock outcropping habitats (Fig. 2d), found 3 active nests, head many murrelets calling on the coloby at night, and roughly estimated 100-300 pairs (Carter \& de Forest 1993a,b, 1994; Carter et al. 1994; WBSJ 1994). On boat trips from Kozushima to Tadanaejima and return on 24 April, no murrelets were seen on the water (Carter \& de Forest 1994a). On 10 April 1994, a team of Japanese and U.S. biologists found 6 nests, including 2 active nests and 4 broken eggshells at nest sites (Carter et al. 1994). Four nests were found in a detailed search of rock outcropping habitats Two nests were found in grass habitats that are extensive and were not completely searched. Two broken eggshells also were found away from nest sites. On 6 April 1995, a team of Japanese and U.S. biologists found one freshly broken eggshell and two old broken eggshells in rock outcropping habitats 
(Ochikubo 1995).

ZENISU: The status of nesting habitats on this isolated collection of small unpopulated rocks is not known. The largest rock is $10 \mathrm{~m}$ in height (N. Oka, pers. comm.). No records are available and surveys have not been conducted.

MIYAKEJIMA: This large, heavily-populated, island (5,514 hectares) surrounds a large volcanic cone (Oyama Mountain, $815 \mathrm{~m}$; active in several recent years between 1983 and 2000) and Sanbondake is a satellite island. Coastal areas of Miyakejima tend to be low lying (20-30 m cliffs) and no suitable murrelet nesting habitat appears to occur. Moyer (1957) made a thorough but unsuccessful search near Ma Point on 25 May 1953, because he had seen a large concentration of murrelets at sea nearby previously that season. Subsequent observations have confirmed the regular presence of feeding murrelets at marine convergences off Miyakejima (J. T. Moyer, pers. comm.). These murrelets appear to belong to Sanbondake and possibly other colonies (see above). No evidence of breeding has been obtained.

Sanbondake (alternate name Onoharajima): This small unpopulated island off Miyakejima has little vegetation and smaller rocks occur nearby but do not appear to have suitable nesting habitat. Murrelets have been found nesting in crevices within a large boulder pile and in rocks along the top of the beach on the northeast side. Kiyosu (1952) reported breeding at Sanbondake and Austin \& Kuroda (1953) reported nesting in the past without details. On 10 May 1930, 11 eggs were collected at "Miyakejima" (probably Sanbondake; KC \#1677). On 11 May 1934, 5 clutches were collected at Sanbondake (YIO \#85-1323 to 85-1327). In addition, 3 adults were collected by Kiyosu at Sanbondake on this date, likely at the colony when eggs were collected (NSMA \#10147, 10148, 10149).

Moyer (1957) reported more than 50 murrelets off Ma Point on the southwest side of Miyakejima and collected 12 murrelets off the east side of Sanbondake on 5 April 1953, including one female with a "developed egg" in the oviduct. C. M. Fennell (BMVZ \#128733) collected one specimen of an adult female with "enlarged ovary" on this date, but Moyer (1957) did not mention Fennell. We have not discovered museum specimens to account for the other 11 murrelets collected. On 17 April 1953, an adult also was collected at Sanbondake (BM \#1995.7.1). Presumably, this bird was collected at sea because Moyer (1957) did not note this trip. On 26 May 1953, J. T. Moyer landed at Sanbondake after it had been bombed by the U.S. Air Force (see Figs. 2e, $f$ and discussion) and a "thorough search yielded no murrelets, but there was limited evidence of breeding. Several grass nests were found tucked far under large boulders, and broken egg-shells were numerous. Under one boulder I counted seven nests. The evidence seemed to indicate that at least a few birds may have reared young in 1953. I was able to salvage a few skeletons of both murrelets and shearwaters (Puffinus [sic] leucomelas).... (CNHM, 3 skins; UMMZ, 3 skeletons)." In fact, at least six skeletons were preserved as UMMZ specimens (\#152355-152360).

J. T. Moyer (5 May 1957 unpubl. correspondence to R. W. Storer, UMMZ) found 20 nests at Sanbondake in early April 1957: eleven with one egg and nine with two eggs. J. 
T. Moyer noted evidence of predation (see discussion) and commented that his "impression is that this species is in danger of disappearing if, as everyone says, the Sanbondake colony is the largest one." On 11 May 1957, J. T. Moyer found "several nests with eggs and four nests with young. The nests with eggs were either about ready to hatch or in the process of hatching... I found several other nests where the eggs had hatched, but no young could be found. In one, the chick scurried off among the rocks, and I imagine this is what happens most of the time (and probably explains the failure of find young in my May trip of 1953). I collected three chicks for you...”. At least four chicks were preserved as specimens (USNM \#564990; UMMZ \#152743, 152744, 152745). On 29 April 1958, an adult, an egg (clutch size unknown), and another egg from a clutch of two eggs were collected at Sanbondake (KC \#58142, 58/5, 58/6). On 3 May 1959, Moyer collected an adult, two single-egg clutches, and one egg from a two-egg clutch at Sanbondake (KC \#3082/59090, 59/5, 59/6, and unknown number).

OSJ (1974) and Higuchi $(1974,1979)$ reported breeding at Sanbondake. Higuchi (1979) noted that "the only place where breeding is confirmed to exist is the lower part of the largest of 6 boulders, a place made of rocks rounded up by the washing waves...". Hasegawa (1984) and Brazil (1991) reported nesting at Sanbondake without details. In April 1985, H. Hasegawa found nests of Japanese Murrelets at Sanbondake (H. Hasegawa, unpubl. data). In 1992, J. T. Moyer (pers. comm. in Carter et al. 1994) reported finding two nests at Sanbondake. On 7 May 1992, WBSJ (1993) conducted a fishing-boat survey between Miyakejima and Sanbondake (07:20-09:10) and counted 41 murrelets. Later the same day, 21 murrelets were observed from Sanbondake to Miyakejima (12:4715:50).

On 11 April 1994, a team of Japanese and U.S. biologists conducted a complete search of the boulder area and nearby accessible areas and found evidence for 9 nests, including 6 active nests, 1 broken eggshell at a nest site, and 2 broken eggshells associated with potential nest sites (Carter et al. 1994, Moyer 1994). In 1994, nests were mainly found in the same large boulder pile (Fig. 2f) as in 1953 and 1957 (Moyer 1957, J. T. Moyer, pers. comm.). A rough estimate of 75-100 pairs was determined. Between Kozushima and Sanbondake (07:00-10:00), 12 murrelets were observed from a fishing boat on 11 April 1994. Later the same day, 60 murrelets were observed between Sanbondake and Miyakejima (14:00-17:00). On 14 and 17 April 1995, a team of Japanese and U.S. biologists counted 20 and 39 murrelets (respectively) at sea between Miyakejima and Sanbondake (Ochikubo 1995). On 1 May 1995, one adult was collected (YIO 950245). Other visits to Sanbondake occurred in 1995 to measure breeding success (J. T. Moyer, pers. comm.) but details are not available. Yamamoto (2001) reported murrelets at sea between Miyakejima and Sanbondake since 1995 and considered murrelet breeding failures at Sanbondake were the result of high predation on adults and eggs by Jungle Crows (Corvus macrorhynchus).

MIKURAJIMA: This large island (1,969 hectares) surrounds a large volcanic cone (Oyama Mountain) and has Motone as a satellite island. Mikurajima has been populated at least for a few hundred years (Oka 1994) and has a natural forest used for burrow 
nesting by a very large colony of Streaked Shearwaters (Hasegawa 1984, Jida et al. 1987, Brazil 1991). No murrelet nesting areas have been described but current breeding may occur in inaccessible cliffs and steep slope areas (100-300 m high) around much of the island. Kiyosu (1952) lists Mikurajima as breeding grounds but evidence of breeding has not been obtained. Murrelets are known to feed at sea near Mikurajima at times (J. T. Moyer, pers. comm.). However, these murrelets may nest at Motone or Sanbondake.

Motone: This small unpopulated rock has little or no vegetation and murrelets appear to nest in rock crevices. In 1985 or 1986, H. Hasegawa found nests of Japanese Murrelets at Motone (H. Hasegawa, unpubl. data).

INANBAJIMA: The status of nesting habitats on this small, isolated and unpopulated rock is not known. No records are available and surveys have not been conducted. Brown Boobies Sula leucogaster are known to nest at this island, indicating suitable nesting conditions for seabirds and low human disturbance (Hasegawa 1984, Brazil 1991).

\section{Central Section of the Izu Islands}

HACHIJOJIMA: This large island (6,818 hectares) surrounds two large volcanic cones (Higashi and Nishi mountains), is heavily populated (once a penal colony), and coastal areas are mainly low lying with some steep slopes. No suitable nesting habitat appears to occur. Hachijojima has two satellite islands: Hachijokojima and Kojine. Momiyama (1924) stated that breeding occurred on Hachijojima, based on a specimen collected (presumably at sea) between May and December 1922. Kiyosu (1952) listed Hachijojima as breeding grounds but evidence of breeding has not been obtained. Five adult specimens exist that were obtained off Yaene, Hachijojima, as follows: one adult, 1 April 1924 (YIO \#3536); one adult, 23 April 1924 (YIO \#1073); and 3 adults, 4 April 1925 (YIO \#3537, 3538, 3539). Other Hachijojima specimens include: one adult collected by G. Okuyama (in the collection of T. Momiyama) on 29 April 1932 (MCZ \#277533); one adult collected by O. L. Austin, Jr. on 11 May 1947 (MCZ \#276101); and one adult collected by C. M. Fennell "offshore of Hashijojima" on 4 April 1949 (BMVZ \#127076). Some or all of these murrelets may have nested at nearby Kojine, which occurs near Yaene. Despite unlikely nesting by Japanese Murrelets, Streaked Shearwaters nest at Hachijojima, indicating low impacts from introduced mammalian predators (Hasegawa 1984, Brazil 1991).

Hachijokojima: This small island off Hachijojima has low-lying coastal areas. No suitable nesting habitat appears to exist. No records are available and surveys have not been conducted.

Kojine: This small rock off Hachijokojima is covered with substantial vegetation and is not populated. Murrelet nests occur in rock crevices under vegetation and in inaccessible areas. Murrelet nests were first discovered in 1991 (H. Hasegawa, unpubl. data). In 1992, K. Ono studied Japanese Murrelets at Kojine (Ono 1993b). In accessible areas, he studied 5 nests in detail and saw murrelets entering or leaving another 10 nests. Including inaccessible areas on the back side, a total breeding population of 20-30 breeding pairs was estimated (K. Ono, unpubl. data; also see Gaston \& Jones 1998). Moyer (1994) recalled 
visiting Kojine in the 1950s but could not recall if evidence of nesting by murrelets was found (J. T. Moyer, pers. comm.). No specimens were located.

AOGASHIMA: This isolated, large, but little populated island (523 hectares) surrounds a large volcanic cone (Maruyama Mountain) and has extensive cliffs and steep slopes around much of the island. It is not clear if suitable nesting habitats exist. No records are available and surveys have not been conducted.

BEYONEIZU-RETSUGAN (alternate name BAYONNAISE ROCKS) AND MYOJINSHO: The status of nesting habitats on these two small nearby rocks is not known. No records are available and surveys have not been conducted.

SUMISUJIMA (alternate name SMITH ISLAND): This isolated collection of small rocks is vegetated and mainly low lying but it is not clear if suitable nesting habitats exist. No records are available and surveys have not been conducted. Brown Boobies are known to nest on this island, indicating suitable nesting conditions for seabirds and low human disturbance (Hasegawa 1984, Brazil 1991).

\section{Southern Section of the Izu Islands}

TORISHIMA: A single volcanic cone forms this isolated island $\left(4.8 \mathrm{~km}^{2}\right)$. Murrelets have been found nesting in the abandoned burrows of petrels and perhaps in rock crevices. Breeding was reported by Yamashina (1936), OSJ (1942), and Kiyosu (1952). Early adult specimens were obtained as follows: 15 February 1930, one adult, Meijiura, Torishima (YIO \#2211); 5-7 April 1932, four adults on the "north coast of Torishima" (YIO \#12564, 12565, 12566) or "7 km from Torishima" (UMMZ \#134875); 8 April 1933, two adults (YIO \#13233, 13234) and two chicks (YIO \#13236, 13237); and January 1935, one adult (YIO \#18014). Early egg records were: 4 clutches from "western coast of Torishima" on 5-7 April 1932 (YIO \#85-1312, 85-1314, 85-1315, 85-1317); and 2 clutches from "Torishima" on 8 April 1933 (YIO \#85-1313, 85-1316, 85-1321). Kiyosu (1952) reported that murrelets used "the old nests of Oston petrels [Tristram's Storm-Petrel] (about $13 \mathrm{~cm}$ in diameter and about $20 \mathrm{~cm}$ deep) in the sand or in the grassy undercover". OSJ (1974), Hasegawa (1984) and Brazil (1991) reported breeding without details, Small numbers of murrelets are thought to still nest at Torishima. An eggshell was collected by H. Hasegawa in 1994 (Ono 1995, Tsurumi et al.2001). On 4 March 2000, murrelets were head calling at 05:00 and a female with an egg in its oviduct was found dead later in the day among large boulders at the base of a vertical rock cliff at Hatsune-zaki, representing the earliest known egg-laying date in the Izu Islands (Tsurumi et al. 2001). Murrelets also were head calling at 22:00 on 22 February 2001 at Hatsune-zaki (Tsurumi et al. 2001).

SOFUGAN: This small isolated island is vegetated and mainly low lying but it is not clear if suitable nesting habitat exists. No records are available and surveys have not been conducted. Brown Boobies may nest at this island, possibly indicating suitable nesting conditions for seabirds (Hasegawa 1984, Brazil 1991). 


\section{Discussion}

Breeding Distribution: After first collection of the Japanese Murrelet in the Izu Islands in 1877, breeding was first documented through egg specimens in 1901 at Kozushima. Austin \& Kuroda (1953) stated that the Japanese Murrelet "is found most certainly at all times, however, in and around the Izu Islands from O-shima southwards. I collected three adults there 5, 11, and 16 May 1947, and saw four others in April 1949 when I searched unsuccessfully for its nest on Shikine, Kozu, and Sanbondake (near Miyake) islands. It has been found nesting in the past on these islands and on Torishima in the Izus, ...". Higuchi (1979) stated: "Thus, all areas from Oshima to the Tori islands have been listed at least once as breeding ground. The breeding records are certain for Shikine, Kozu, Sanbondake, and Tori islands. We see no records concerning the other islands. Among the Shikine, Kozu, Sanbondake, Tori islands for which there are breeding records, there are, since the end of the war, breeding records for the Sanbondake island only mainly during the seventies. So, the fact of present breeding is uncertain for the other aforementioned islands, and there seems to be a need for a meticulous examination of the archipelago". Certainly, much confusion has existed about the breeding status of murrelets at various Izu Islands over time and still exists at several islands.

By the late 20th century, our collation of available information has confirmed breeding at 11 islands: Udonejima, Niijima, Shikinejima, Hanshima, Kozushima, Onbasejima, Tadanaejima, Sanbondake, Motone, Kojine, and Torishima. Breeding may occur at present or may have occurred in the past at other locations in the Izu Islands. In particular, undocumented breeding is most likely at small uninhabited islands near known colonies that have not been surveyed (i.e., Zenisu, Inanbajima). Breeding does not appear to occur at present at Jinaijima but murrelets may have been extirpated before documentation or a few might nest in inaccessible habitats. Breeding habitats do not apparently exist in low-lying coastal areas at Miyakejima, Hachijojima, and Hachijokojima. Breeding has not been documented but may occur at inaccessible areas of some of the larger islands with steep topography located near known colonies (e.g., Oshima, Toshima, and Mikurajima). Use of similar inaccessible habitats by the closely-related Xantus's Murrelet apparently occurs in the Channel Islands off southern California, USA, based in surveys in the 1990s (Drost \& Lewis 1995; McChesney et al. 2000; Hamer \& Carter 2002; H. R. Carter, unpubl. data). In the Izu Islands, survey efforts in the 1980s and 1990s have found recent evidence of nesting at certain known colonies and supported extirpation at Shikinejima. However, efforts to date have not focused on discovering undocumented colonies. Recent confirmation of breeding is lacking at Udonejima and Niijima (especially Cape Neuki). Most of the southern Izu islands (except Torishima) have not been adequately surveyed to determine if breeding or breeding habitats occur or not (Aogashima, Beyoneizu-Retsugan, Myojinsho, Sumisujima, and Sofugan). Without doubt, additional surveys of Japanese Murrelet and other seabird colonies are needed in many parts of the Izu Islands. 
Population Size and Trends: Due to inadequate data on numbers of breeding murrelets, it has been difficult to ascertain population size and trends of the Japanese Murrelet in the Izu Islands. However, several pieces of evidence suggest that a large decline in numbers has occurred at certain colonies over the 20th century: 1) breeding apparently no longer occurs in late century at Shikinejima and Kozushima where nesting was noted in early century, although breeding habitat still exists and current breeding is still possible; 2) loss of a large portion of breeding habitat has occurred at Sanbondake due to post-war bombing in mid-century (see below); and 3) relatively large numbers of murrelet nests reported by egg harvesters at Kozushima and Sanbondake in early century are much higher than found in surveys of existing colonies in late century. Based on little available information, Higuchi (1974) estimated that a few hundred or a few thousand murrelets might nest in the Izu Islands. Hasegawa (1984) reported a population size of 1,000 birds in the Izu Islands, based on more information by the early 1980s (e.g., Higuchi 1979). Mochizuki \& Ueta (1996) further reported a decline in numbers of murrelets counted at sea from ferries between 1982 and 1995 in the northern Izu islands between Oshima and Niijima. Surveys of at-sea foraging areas between Miyakejima and Sanbondake have shown consistent use of this foraging area over time (Moyer 1957, Carter et al. 1994, Ochikubo 1995). However, murrelets likely feed there because prey are concentrated by predictable convergences and murrelets may travel long distances from various colonies to forage. The three largest existing colonies in the 1990s appear to be Tadanaejima, Onbasejima, and Sanbondake. Recent estimates totaled 270-580 pairs of breeding murrelets at four islands and another 100-300 pairs may nest at other known colonies without recent estimates. Thus, the current breeding population in the Izu Islands appears to range between about $350-850$ breeding pairs (Table 1). All recent estimates are rough but have attempted to reflect available evidence of murrelet nests, birds heard calling on the colony at night, birds seen at sea, and potential amount of nesting habitat.

The Japanese Murrelet population in the Izu Islands roughly constitutes about 10$40 \%$ of the world population, based on recent global estimates ranging between 2,000 and 5,000 pairs (Ono 1993a, 1996, Gaston \& Jones 1998). No longer are the Izu Islands the stronghold of this rare species, as thought by Austin \& Kuroda (1953) and Brazil (1991). Instead, most of the global population now breeds in the Kyushu area (Ono 1993a, 1996). However, in early 20th century, numbers of murrelets in the Izu Islands were much larger, perhaps in the many thousands of pairs, and likely did form the numerical center of the species global range in the past. Within the Izu Islands, the current population center based on recent estimates occurs between Kozushima and Miyakejima. In the past, extensive nesting also appeared to occur in the Niijima area but now breeding may be limited there. One small colony ( $<10$ pairs; Brazil 1991) near the Izu Peninsula is known (i.e., Mikomotojima; see Fig. 1) and likely belongs to the same geographic population as the Izu Islands. It is possible that nesting occurred previously at Oshima and Toshima. These islands are closest to Tokyo Bay and small numbers of breeding murrelets may have been extirpated. Long-term monitoring programs are needed to better measure population trends and breeding success at important colonies in the Izu Islands. 
Human Settlement: The Izu Islands have been populated by humans since before the feudal period or well over a thousand years (see Fig. 3a). Prior to 1900, settlements occurred on several islands (e.g., Oshima, Toshima, Niijima, Shikinejima, Kozushima, Miyakejima, Mikurajima, Hachijojima, and Aogashima). Settlements have not developed at some small southern Izu Islands (Beyoneizu-Retsugan, Myojinsho, Sumisujima, and Sofugan). Torishima was settled in 1887, with only 10-50 residents until 1900. Further settlement was slowed by multiple volcanic eruptions that resulted in many human deaths (Brazil 1991).

Settlement by humans, and introduction of rats and feral cats, has likely restricted most Japanese Murrelets to nesting at small unpopulated Izu Islands for several centuries, especially at: Udonejima, Hanshima, Onbasejima, Tadanaejima, Sanbondake, Motone, and Kojine. The expanding population of humans living locally at the Izu Islands also has been augmented in the 20th century by large numbers of temporary residents and tourists who come to the islands for various reasons, especially commercial and recreational fishing, sun bathing, and nature viewing (i.e., ecotourism). At Torishima, cattle grazing also may have affected nesting habitats for murrelets, as it has for the Short-tailed Albatross Diomedea albatrus (Hasegawa 1984, Brazil 1991). The increase in human use of the Izu Islands has led to an increase in many human activities which probably have impacted Japanese Murrelets at remaining colonies, although loss of a breeding colony appears to have occurred only at Shikinejima. In particular, human use of all unpopulated islands should be carefully controlled and most people (i.e., except during biological studies) should not be allowed to live on these islands.

Human consumption: In the 19th and early 20th centuries, local people harvested murrelet eggs at several locations in the Izu Islands. Such harvesting was documented to be extensive at Udonejima, Niijima (Cape Neuki), Hanshima, Kozushima, and Sanbondake (see above; Carter et al. 1994, Ochikubo 1995). The best documentation of such harvesting is available for Sanbondake. J. T. Moyer (5 May 1957 unpubl. correspondence to R. W. Storer, UMMZ) "heard stories from the islanders of egg-raids in pre-war years where they took hundreds of eggs, but I was only able to find a total of 30 eggs" in early April 1957. Carter et al. (1994) reported that a fisherman stated that in the pre-war and war years, that nests at Sanbondake previously occurred in large numbers in crevices located in loose rocks along the top of the beach. Fishermen would load baskets of eggs from the beach area and return them to Miyakejima for consumption. However, during post-war occupation, egg collecting stopped, partly because Sanbondake had become a bombing target. Egg harvesting during and after World War II also likely increased at several colonies due to local food demands. Such harvesting likely contributed (along with other factors; see below) to the loss of nesting murrelets at Kozushima, Shikinejima, and possibly Niijima. At these islands, murrelets likely nested in small areas with limited nesting habitats that were easily accessible to humans. Presumably, less frequent egg harvesting at larger colonies on more inaccessible islands did not result in colony extirpations. Harvesting stopped in the 1950 s and 1960 s, probably due to a combination of: increased availability of food from other sources; changes in food preferences; and 

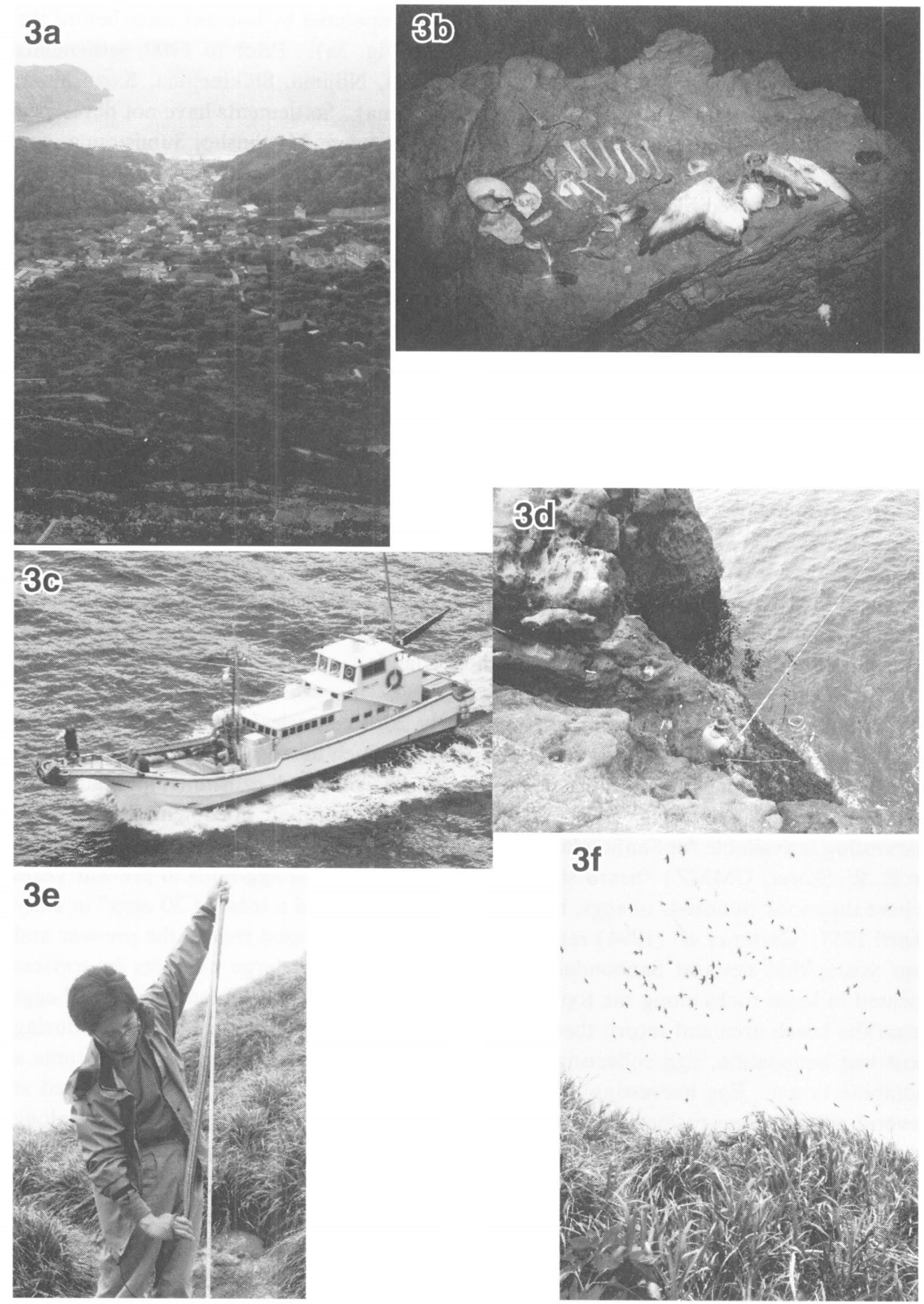
reduced availability of murrelet eggs and adults at colonies. Extensive harvesting of Streaked Shearwaters at Mikurajima also had reduced dramatically by the 1950s, although about one thousand per year are still killed as pests because their burrows cause trees to topple (Kurimoto 1936, Ikeda 1954, Brazil 1991). Occasional harvesting of murrelet eggs may still persist. Education of local people and new regulations would help prevent any further harvesting.

Introduced predators: Rats (Rattus rattus, $R$. norvegicus) have been introduced by humans to many of the Izu islands, including: Oshima, Toshima, Niijima, Shikinejima, Miyakejima, Mikurajima, Hachijojima, Aogashima, and Torishima (Nishikata 1986, Hasegawa \& Moriguchi 1989). Some rats also may occur on Onbasejima, based on caches of bird remains found in 1994 (Carter et al. 1994; see Fig. 3b). Rats are well known to impact murrelets at Koyashima near Honshu (Takeishi 1987) and may have contributed to the extirpation of nesting murrelets from Niijima, Shikinejima, and Kozushima, along with human consumption. Rats and cats probably severely impacted murrelets and Tristram's Storm-Petrels nesting at Torishima. Feral cats have died out and murrelets are thought to still nest (Ono 1955, Hasegawa 1984, H. Hasegawa, unpubl. data). Rats and cats also impact Streaked Shearwaters at Mikurajima, although the large shearwater colony still thrives. Rats should be eradicated immediately from the smaller islands of Torishima and Onbasejima. Rat and cat eradication at large islands (e.g., Mikurajima) will require much greater effort. In addition, actions should be taken to prevent the spread of rats to other Izu Islands. Weasels were introduced to Toshima, Miyakejima, Hachijojima, and Aogashima. They probably do not affect Japanese Murrelets but can impact other seabirds such as Streaked Shearwaters (Hasegawa 1999).

Bombing of Sanbondake: Austin \& Kuroda (1953) first noted that "The Izu Island population has recently suffered a set-back from the use of Sanbondake, its principal known remaining nesting site, as a bombing target by the U.S. Air Forces in 1951 and 1952. Although the target area was shifted elsewhere the moment the Air Command was informed of the harm being done, it is feared that the almost daily bombing of the site during two nesting seasons has done irreparable damage to the dwindling Japanese Murrelets". On 26 May 1953, Moyer (1957) landed at Sanbondake and recorded that "the breeding grounds [were] a grim reminder of two years of use as an U.S. Air Force bombing range (1951-52). Twisted bomb fragments and carcasses of shearwaters and murrelets littered the flat rocky strip of shore where the birds formerly bred. A thorough

Fig. 3. Conservation issues facing Japanese Murrelets in the Izu Islands (all photos by H. R. Carter): a) Town site at Kozushima, with Onbasejima (faint) in background, 23 April 1993; b): Remains of Japanese Murrelets from a possible rat cache at Onbasejima, 8 April 1994; c) Surf fishing boat at Tadanaejima, 10 April 1994; d) Surf fisherman with bait on rocks at Tadanaejima, 10 April 1994; e) Rat Snake being measured by M. Hasegawa at Tadanaejima, 24 April 1993; and f) Jungle Crows at Tadanaejima, 10 April 1994. 
search yielded no murrelets, but there was limited evidence of breeding... [see above for details]". This bombing apparently resulted in the substantial loss of breeding habitat and killed many adults at this colony. In 1994, Carter et al. (1994) reported that a fisherman recalled that before the bombing that the highest peak of Sanbondake was a single cone-shaped rock whereas at present it is bifurcated by a large split in the cone (Fig. 2e). Numbers of murrelets currently nesting at Sanbondake probably are much lower than the hundreds or perhaps over a thousand nests that may have occurred historically, but the colony has persisted, at least with cessation of egg harvesting and bombing.

Surf Fishing: Extensive recreational surf fishing has occurred in the Izu Islands since the 1960s and continues to increase. It is a major form of tourism with large economic benefits to local residents. Fishermen are dropped off on small offshore rocks and islands for surf casting (Figs. 3c, d). They can impact murrelets in two major ways: 1) by walking on murrelet nesting habitats, fishermen can crush adults and eggs located in grass and soil areas and destroy nesting habitat (e.g., Tadanaejima); and 2) by leaving piles of bait and trash at fishing locations, fishermen provide food for Jungle Crows, Black-tailed Gulls Larus crassirostris, and other potential scavengers which serves to attract these murrelet predators to nesting islands and increase predator populations (e.g., Tadanaejima, Onbasejima, Sanbondake; Higuchi 1979, Carter et al. 1994). Similar problems have been noted for Japanese Murrelets at Biro Island, Kyushu (Ono 1993a, Ono et al. 1994, 1995). Education of fishermen and local residents and new regulations may reduce or prevent such impacts. Island wardens could assist education and help enforce regulations at problem colonies (i.e., Udonejima, Hanshima, Tadanaejima, Onbasejima, and Sanbondake).

Natural Predators: Murrelet eggs and Tristram's Storm-petrel chicks are major diet items of rat snakes (Elaphe quadrivirgata) at Tadanaejima (Fig. 3e). These snakes exhibit island gigantism and achieve large sizes with adults averaging 1,485 g (Hasegawa \& Moriguchi 1989; M. Hasegawa and A. Mori, unpubl. data). Rat snakes are distributed widely in the Izu Islands (Oshima, Toshima, Udonejima, Niijima, Shikinejima, Kozushima, Tadanaejima, and Mikurajima) but are currently only known to overlap with and prey upon nesting Japanese Murrelets at Tadanaejima and Udonejima (Hasegawa \& Moriguchi 1989). In fact, Tadanaejima is also known as "Hebijima" or snake island. At these colonies, snakes undoubtedly affect reproductive output but it is unclear to what degree without conducting specific studies. Less than 200 individual snakes occur on each island. With their low metabolic rates and long history of co-existence with murrelets at these islands, it is likely that this native snake is not a serious problem unless murrelet populations reach extremely low levels. Gigantic snake populations on islands with seabird colonies also have been noted in the Ryukyu Islands, a small coastal island in the Japan Sea, and islands between southern Australia and Tasmania (Schwaner 1985, Kohno \& Ota 1991, Mori 1994).

While Peregrine Falcons (Falco peregrinus) are well known as seabird predators in the western North America, they are uncommon in Japan (Brazil 1991). However, 
falcons occur regularly at Biro Island, and kill adult murrelets (Carter et al. 1994, Ono et al. 1995). Small numbers of falcons are resident in the Izu Islands and feed extensively on murrelets at Sanbondake. J. T. Moyer (5 May 1957 unpubl. correspondence with R. W. Storer, UMMZ) noted on a visit to Sanbondake in early April 1957 that he "found a number of badly mangled carcasses, and later a peregrine passed screaming overhead." Higuchi (1979) noted that "Often numerous dead bodies of adult individuals are observed at the breeding grounds during the breeding season. Over 30 were recorded in May 1973 at Sanbondake...". On 11 April 1994, six dead adults were found, presumably due to falcon predation (Carter et al. 1994). Falcon numbers appear to be increasing slightly over the last decade at Miyakejima (J. T. Moyer, pers. comm.). Falcon predation should be monitored at Sanbondake to determine its extent. On 27 April 1993, a juvenile falcon also was noted at Tadanaejima (Carter \& de Forest 1994a). A fresh-dead adult found at Onbasejima on 8 April 1994 probably was killed by a falcon (Carter et al. 1994).

Jungle Crows are common throughout Japan and breed throughout the Izu Islands (Brazil 1991). Numbers have likely increased in the Izu Islands in recent years, due to increased food availability from human sources in towns and from commercial and recreational fishing activities. J. T. Moyer (5 May 1957 unpubl. correspondence with R. W. Storer, UMMZ) noted on a visit to Sanbondake in early April 1957 that "To make matters worse, a crow was caught in the act of stealing eggs, and several shells were found in the vicinity." Large numbers (75-150) of crows were noted at Tadanaejima in 199495 (Fig. 3f), smaller numbers in 1993 (10-15), and apparent crow predation of eggs was noted (Carter \& de Forest 1994a, Carter et al. 1994, Ochikubo 1995). Jungle Crows are well known predators of murrelets and their eggs at Biro Island (Ono et al. 1994, 1995). Changes to surf fishing practices and human refuse in towns, especially at Kozushima, Niijima, and Miyakejima, are needed to reduce crow numbers, reduce crow use of small unpopulated islands, and reduce crow predation at murrelet nesting islands. At Miyakejima, crows have been recently noted scavenging on dead frogs found dead on streets after being hit by cars ( $\mathrm{H}$. Higuchi, pers. comm.). It is not known if the crow population has increased since the introduction of frogs to Miyakejima. Among natural predators, Jungle Crows are of the greatest concern because they occur widely in high numbers and can eat large numbers of eggs (Ono et al. 1994, 1995, Carter et al. 1994, Moyer 1994). Specific studies are needed to better document crow predation, human refuse, other factors affecting crows, as well as to develop solutions.

Black-tailed Gulls are the most abundant gull in Japan and occur widely on marine coasts (Brazil 1991). These gulls are potential predators of murrelets, especially where gulls nest at the same islands as murrelets (i.e., Onbasejima). Gull pellets with possible murrelet remains were found at Tadanaejima on 26 April 1993 (Carter \& de Forest 1994 a) and two dead adult murrelets were found at Onbasejima on 8 April 1994 which may have been killed by gulls (Carter et al. 1994). Gull predation should be monitored to determine its extent.

Volcanic Eruptions: The Izu Islands are renown for their frequent volcanic eruptions, most recently the 2000 eruption at Miyakejima. In many cases, the entire communities of 
these islands have been evacuated because a large portion of these islands often are covered with volcanic ash. During such eruptions, murrelet nesting habitat may be lost for a period of time and/or replaced with additional habitat. At Torishima, major volcanic eruptions in 1902, 1933 and 1941 destroyed or affected nesting habitats for Short-tailed Albatross and the entire island was covered with lava during the 1941 eruption. A few remaining albatrosses recolonized the island in 1950 (Hasegawa 1984, Brazil 1991). Breeding records of Japanese Murrelets at Torishima were obtained mainly in 1932-33 (see above). Murrelets also may not have nested at Torishima for some period after the eruption or may no longer nest there. Additional efforts are needed to provide recent confirmation of breeding at Torishima.

Anthropogenic Mortality At Sea: Japanese Murrelets are known to be killed in gill nets in coastal waters around Japan, as well as in regions offshore of Japan in the North Pacific (DeGange \& Day 1991, DeGange et al. 1993). Piatt \& Gould (1994) estimated that between 98-417 and 40-160 Japanese Murrelets were killed off northwestern Honshu (within the Western Drift Net Fishing Area) between August and December in 1990 and 1991 , respectively. This level of mortality reflected $1-10 \%$ of the world adult population that had been estimated roughly at 4,000 birds. It is not known how this mortality varies between years or which colonies are affected but it is likely that at least some murrelets from the Izu Islands are killed in these offshore gill nets. Brazil (1991) surmised that some murrelets (especially from the Izu Islands) disperse northwards off the coasts of northern Honshu and Hokkaido. However, some murrelets (perhaps from Kyushu colonies) disperse south to the Nansei Islands between Kyushu and Taiwan and others (perhaps from colonies off western Honshu) disperse north in the Sea of Japan as far as Sakhalin.

Extensive gill-net fishing also occurs in nearshore waters around the Izu Islands. Fishermen at Kozushima reported catching small numbers of murrelets in gill nets (Carter et al. 1994). Ochikubo (1995) also reported that Niijima fishermen reported that murrelets were often caught in gill nets "up to 3 or 4 per night" near Udonejima. Unfortunately, no specific fishery observer data are available for nearshore gill-net fishing near colonies in the Izu Islands to estimate the actual extent of such mortality, which appears to be substantial and directly affects Izu colonies.

Mortality of Japanese Murrelets was documented during the 1997 Nakhodka oil spill and has probably occurred during oil spills in the Japan Sea (Kazama 1971, Helm et al. 1997, JAS 1997, Fries et al. 1998). Small numbers may be killed regularly by oil pollution in the Izu Islands, especially in northern islands closer to oil-tanker traffic lanes near Tokyo Bay. Little or no effort has been made to detect oiled birds near the mouth of Tokyo Bay or in the Izu Islands.

\section{Acknowledgments}

Studies of Japanese Murrelet colonies in the Izu Islands in the 1980s and 1990s by H. Hasegawa and $\mathrm{K}$. Ono were supported by Toho University. Japanese and North American surveys in 1992-95 were supported by the Wild Bird Society of Japan, Pacific 
Seabird Group, Japan Alcid Society, and Miyakejima Nature Center, with assistance from: M. Asada, G. Divoky, J. Kato, Y. Kobayashi, J. Minton, A. Mori, K. Nelson, K. Otsuki, J. Piatt, M. Rauzon, and Y. Yamamoto. In 1994-95, the Pro-Natura Fund (Nature Conservancy Society of Japan) supported surveys by the Japan Alcid Society. In 1995, surveys by the Japan Alcid Society were supported by a Sasakawa Scientific Research Grant on "Seabird predation by introduced species". Izu fishermen N. Hamakawa, K. Kitamura, K. Miyata, H. Sasaki, and A. Uematsu provided valuable information on past egg harvesting and mortality in gill nets. We appreciated the accommodations and boat transportation provided by T. Hamakawa of the Mansaku Maru inn at Kozushima in 1993-95 and other years. H. Sasaki provided boat transportation at Miyakejima and Sanbondake. Valuable comments and clarifications on this paper were provided by $\mathrm{N}$. Oka.

Valuable specimen information was provided by: American Museum of Natural History (AMNH), New York, New York; British Museum (BM), Tring, England; Field Museum of Natural History (CNHM), Chicago, Illinois; Kobayashi Collection (KC), Tokyo, Japan; Museum of Comparative Zoology (MCZ), Harvard University, Cambridge, Massachusetts; Museum of Vertebrate Zoology (BMVZ), University of California, Berkeley, California; National Science Museum (NSMA), Tokyo, Japan; Natural History Museum (NHBE), Berne, Switzerland; U.S. National Museum of Natural History (USNM), Smithsonian Institution, Washington, D.C.; University of Michigan Museum of Zoology (UMMZ), Ann Arbor, Michigan; and Yamashina Institute of Ornithology (YIO), Tokyo, Japan.

\section{Literature Cited}

Austin, O. L., Jr. \& Kuroda, N. 1953. The birds of Japan: their status and distribution. Bull. Mus. Comp. Zool. Harvard 109(4): 279-613.

Baird, S. F., Brewer, T. M. \& Ridgway, R. 1884. The water birds of North America. Vol. II. Mem. Mus. Comp. Zool. Harvard Coll. Vol. 13. 549 pp.

Brazil, M. A. 1991. The birds of Japan. Smithsonian Institution Press, Washington, D.C.

Carter, H. R. \& de Forest, L. 1993a. Pacific Seabird Group goes to Japan: Part 1 (First few days). Pacific Seabird Group Bulletin 20(2): 14-17.

Carter, H. R. \& de Forest, L. 1994a. Pacific Seabird Group goes to Japan: Part 2 (Izu Islands). Pacific Seabirds 21(1): 17-21, 25.

Carter, H. R. \& de Forest, L. 1994b. Pacific Seabird Group goes to Japan: Part 3 (Continuing efforts). Pacific Seabirds 21(2): 13-16.

Carter, H. R., Fries, J. N., Ochikubo, L. K., de Forest, L. \& Piatt, J. F. 1994. Conservation of the Japanese Murrelet: joint efforts by the Pacific Seabird Group and Japanese research groups in 1993-1994. Unpublished report, National Biological Survey, Dixon, California.

DeGange, A. R. \& Day, R. H. 1991. Mortality of seabirds in the Japanese land-based gillnet fishery for salmon. Condor 93: 251-258.

DeGange, A. R., Day, R. H., Takekawa, J. E. \& Mendenhall, V. M. 1993. Losses of seabirds in gill nets in the North Pacific. Pages 204-211 in The status, ecology and conservation of marine birds of the North Pacific, ed. Vermeer, K., Briggs, K. T., Morgan, K. H. \& Siegel-Causey, D. Special Publication, Canadian Wildlife Service, Ottawa, Ontario.

Drost, C. A. \& Lewis, D. B. 1995. Xantus' Murrelet (Synthliboramphus hypoleucus). In The birds of North 
America, No. 164, ed. Poole, A. \& Gill, F. The Academy of Natural Sciences, Washington, D.C. and American Ornithologists' Union, Washington, D.C.

Fries, J., Uematsu, K., Takaki, J. \& Sadayosi, T. (Eds.). 1998. [Oil spills and the protection of wildlife: "What have we learned since the Nakhodka spill?"]. Proc. Japan-U.S. symposium, 7 December 1997, Tokyo. Nippon Foundation, Tokyo, Japan.

Gaston, A. J. \& Jones, I. L. 1998. The auks Alcidae. Oxford University Press, New York, New York.

Hamer, T. E. \& Carter, H. R. (Eds.). 2002. Population monitoring of Xantus's Murrelets (Synthliboramphus hypoleucus) at Anacapa Island, California: 2000 annual report. Unpublished report, Hamer Environmental L. P., Mount Vernon, Washington and Humboldt State University, Department of Wildlife, Arcata, California.

Hasegawa, H. 1984. Status and conservation of the seabirds in Japan, with special attention to the Short-tailed Albatross. Pages 487-500 in Status and conservation of the world's seabirds, ed. Croxall, J. P., Evans, P. G. H. \& Schreiber, R. W. International Council for Bird Preservation Tech. Publ. 2, Cambridge, England.

Hasegawa, M. 1999. Impacts of introduced weasel on the insular food web. Pages 129-154 in Tropical island herpetofauna: origin, current diversity, and conservation. Proceedings of the international symposium, "Diversity of reptiles, amphibians, and other terrestrial animals on tropical islands: origin, current status, and conservation", Okinawa, Japan, 6-7 June 1998, ed. Ohta, J., Elsevier, Netherlands.

Hasegawa, M. \& Moriguchi, H. 1989. Geographic variation in food habits, body size and life history traits of the snakes of the Izu Islands. Pages 414-432 in Current herpetology in East Asia, ed. Matui, M., Hikida, T. \& Goris, R. C. Herpetological Society of Japan, Kyoto, Japan.

Helm, R. C., Carter, H. R., Newman, S. H., Fries, J. N., Ono K. \& Sato, M. 1997. Seabird injury and wildlife care during the 1997 Nakhodka oil spill in the Sea of Japan: observations and recommendations by a team of U.S. scientists. Unpublished report, U.S. Fish and Wildlife Service, Ecological Services, Portland, Oregon; U.S. Geological Survey, Biological Resources Division, California Science Center, Dixon, California; and University of California, Wildlife Health Center, Davis, California.

Higuchi, H. 1974. [Miyake Island]. Pages 3-18 in Survey of the status and habitat conditions of threatened species. Unpublished report, Wild Bird Society of Japan, Tokyo, Japan (prepared for Japan Environment Agency, Tokyo, Japan).

Higuchi, H. 1994. [Successful completion of a joint Japan-U.S. survey of the Endangered Japanese Murrelet]. Yacho (570): 18.

Higuchi, Y. 1979. [Breeding ecology and distribution of Japanese Crested Auklet]. Kaiyo to Seibutsu (Aquatic Biology) 1(3): 20-24 (English translation in 1988 by the Canadian Wildlife Service).

Ikeda, S. 1954. To Mikurazima, Izu Is., after Streaked Shearwater. Tori 13: 40-47.

Isobe, S. 1982. Niijima no Chourui [Birds of Niijima Island]. Bulletin of Toseiken (Society of Biological Sciences Education of Tokyo) 18: 26-32.

Isobe, S. 1990. Izushoto no Chourui [Birds of the Izu Islands]. Nihon no Seibutsu [The Natural History of Japan] 4(2):12-19.

Japan Alcid Society (JAS). 1994. [Status and conservation of rare alcids in Japan]. Japan Alcid Society Special Publication No. 1 (ed., Ono, K.). Japan Alcid Society, Chiba, Japan.

Japan Alcid Society (JAS). 1997. [The Nakhodka oil spill and seabirds]. Japan Alcid Society Special Publication No. 2. Japan Alcid Society, Hokkaido, Japan.

Jida, N., Maruyama, N., Oka, N. \& Kuroda, N. 1987. [Structure of a colony of Streaked Shearwaters at Mikura Island]. J. Yamashina Inst. Ornithol. 19: 56-76 (in Japanese with English abstract).

Kazama, T. 1971. [Mass destruction of Synthliboramphus antiquus by oil pollution of Japan Sea]. Misc. Reports Yamashina Inst. Ornithol. 6: 389-398.

Kiyosu, Y. 1952. Nihon Chourui Daizukan III [The Birds of Japan III]. Koudansha, Tokyo, Japan.

Kiyosu, Y. 1965. [The birds of Japan]. Kodansha, Tokyo, Japan.

Kohno, H. \& Ota, H. 1991. Reptiles in a seabird colony: herpetofauna of the Nakanokamishima Island of the Yaeyama group, Ryukyu Archipelago. Island Studies in Okinawa 9: 73-89.

Kurimoto, S. 1937. [Farming the Streaked Shearwaters of Mikura-jima]. Yacho 4: 835-839.

McChesney, G. J., Gress, F., Carter, H. R. \& Whitworth, D. L. 2000. Nesting habitat assessment for Xantus' 
Murrelets and other crevice-nesting seabirds at Anacapa Island, California, in 1997. Unpublished report, U.S. Geological Survey, Western Ecological Research Center, Dixon, California; and Department of Wildlife, Humboldt State University, Arcata, California.

Mochizuki, H. \& Ueta, M. 1996. [Decrease of Japanese Murrelets in Izu Islands, central Japan]. Strix 14: 173176.

Momiyama, T. 1923. Notes on the birds on Oshima, Prov. Izu. Tori 3: 196-213.

Momiyama, T. 1924. A list of birds collected on Hachijojima in the Seven Islands of Izu, Japan. Tori 4: 100109.

Mori, A. 1994. Ecological and morphological characteristics of the Japanese rat snake Elaphe climacophora, on Kanmuri-jima Island: a possible case of insular gigantism. Snake 26: 11-18.

Moyer, J. T. 1957. The birds of Miyake Jima, Japan. Auk 74: 215-228.

Moyer, J. T. 1994. [Japanese Murrelet revisited]. Yacho (572): 27 (English translation in Pacific Seabirds 21 (2): 17).

Namie, M. 1889. [The birds of the Izu Islands]. Dobutsugaku zasshi 1: 329-333.

Nettleship, D. N. \& Birkhead, T. R. (Eds.). 1985. The Atlantic Alcidae. Academic Press, New York, New York. Nishikata, S. 1986. Ecological surveys for the rodents of the Izu islands. Island Life 1(13/15): 145-147.

Ochikubo, L. K. 1995. Japanese Murrelet Izu Islands survey: field observations of Synthliboramphus wumizusume from April to May 1995. Unpublished report, National Biological Survey, Dixon, California.

Oka, N. 1994. Sustainable exploitation of Streaked Shearwaters Calonectris leucomelas on Mikura Island, off the Izu Peninsula, Japan. J. Yamashina Inst. Ornithol. 26: 99-108.

Ono, K. (Ed.). 1993a. [The Japanese Murrelet: Its status and conservation]. Unpublished meeting abstracts of the 1993 meeting of the Japan Ornithological Society at Ehime University, Japan. Translated by John Fries.

Ono, K. 1993b. [Offshore distribution and breeding ecology of the Japanese Murrelet Synthliboramphus wumizusume in Izu Islands]. Unpublished M.Sc. thesis, Toho University, Funabashi, Chiba, Japan. 52 pp.

Ono, K. (Ed.). 1995. [Status and conservation of rore Alcids in Japan]. Unpublished report, Japan Alcid Society, Funabashi, Chiba, Japan

Ono, K. 1996. [The Japanese Murrelet]. Pages 514-519 in Basic sources of aquatic wildlife in Japan (III). Japan Fisheries Resource Conservation Association, Tokyo, Japan.

Ono, K., Fries, J. N. \& Nakamura, Y. 1994. [Crow predation of Japanese Murrelets]. Urban Birds 11: 63-68.

Ono, K., Fries, J. \& Nakamura, Y. 1995. Crow predation on Japanese Murrelets on Biro Island, Japan. Pacific Seabirds 22: 39-40 (abstract).

Ono, Y. 1955. The status of birds at Torishima; particularly of the Steller's Albatross. Tori 14: 24-32.

Ornithological Society of Japan (OSJ). 1942. [A hand list of Japanese birds]. Third Edition. Ornithological Society of Japan, Tokyo, Japan.

Ornithological Society of Japan (OSJ). 1974. [Checklist of Japanese birds]. Fifth Edition. Gakken Press, Tokyo, Japan.

Ornithological Society of Japan (OSJ). 2000. [Checklist of Japanese birds]. Sixth Revised Edition. Ornithological Society of Japan, Obihiro, Japan.

Piatt, J. F. \& Gould, P. J. 1994. Postbreeding dispersal and drift-net mortality of endangered Japanese Murrelets. Auk 111: 953-961.

Schwaner, T. D. 1985. Population structure of black tiger snakes, Notechis ater nigris, on offshore islands of south Australia. Pages 35-46 in The biology of Australian frogs and reptiles, ed. Grigg, G., Shine, R. \& Ehman, H. Surrey Beatty and Sons, Sydney, Australia.

Springer, A. M., Kondratyev, A. Y., Ogi, H., Shibaev, Y. V. \& van Vliet, G. B. 1993. Status, ecology, and conservation of Synthliboramphus murrelets and auklets. Pages 187-201 in The status, ecology and conservation of marine birds of the North Pacific, ed. Vermeer, K., Briggs, K. T., Morgan, K. H. \& Siegel-Causey, D. Special Publication, Canadian Wildlife Service, Ottawa, Ontario.

Takeishi, M. 1987. The mass mortality of Japanese Murrelet Synthliboramphus wumizusume on the Koyashima Islet in Fukuoka. Bull. Kitayushu Mus. Nat. Hist. 7: 121-131.

Takekawa, J. Y. \& Carter, H. R. 1994. The California-Siberia connection: conserving Beringia's avian legacy. Coast and Oceans 10: 28-37. 
Tsurumi, M., Sato F., Hiraoka, T. \& Maeyama, R. 2001. Recent evidence of probable breeding of the Japanese Murrelet Synthliboramphus wumizusume on Tori-shima, Izu Islands, Japan. J. Yamashina Inst. Ornithol. 33: $54-57$.

Wild Bird Society of Japan (WBSJ). 1974. Miyakejima [Miyake Island]. Pages 3-18 in Tokutei Chourui Tou Chousa [Survey of the status and habitat conditions of threatened species]. Unpublished report, Wild Bird Society of Japan, Tokyo, Japan (prepared for the Japan Environment Agency, Tokyo, Japan).

Wild Bird Society of Japan (WBSJ). 1993. [Ecology and conservation of Japanese Murrelets (1992)]. Unpublished report, Wild Bird Society of Japan, Research Division, Tokyo, Japan (prepared for Tokyo Local Government, Tokyo, Japan).

Wild Bird Society of Japan (WBSJ). 1994. [Ecology and conservation of Japanese Murrelets (1993)]. Unpublished report, Wild Bird Society of Japan, Research Division, Tokyo, Japan (prepared for Tokyo Local Government, Tokyo, Japan).

Yamaguchi, T. 1984. Ph. F. von Siebold and H. Bürger's contributions to Japanese ornithology. Calanus [Bulletin of the Aitsu Marine Biological Station, Kumamoto University] 11: 1-152.

Yamamoto, H. 2001. [Miyakejima]. Ornithological News No. 78: 5-7.

Yamashina, Y. 1936. [Habits of Janthoenas janthina and Synthliboramphus wumizusume in the Seven Islands of Izu]. Tori 9: 222-231.

[ ] denotes English translations of Japanese titles.

\section{伊豆諸島におけるカンムリウミスズメ Synthliboramphus wumizusume の現状と保護}

我々は伊豆諸島におけるカンムリウミスズメの繁殖や保全について、さまざまな資料を集め て検討した。1 835 年に種が記載された後、伊豆諸島では 1877 年にはじめて収集され, 1901 年 に繁殖が初記載された。20世紀以後これまで, カンムリウミスズメは11の島々（鵜渡根島, 新 島, 式根島, 早島, 神津島, 恩馳島, 祇苗島, 三本岳, 元根, 小池根, 鳥島) で繁殖が確認さ れ, 7 つの島 (大島, 利島, 地内島, 三宅島, 御蔵島, 八丈島, 八丈小島) では繁殖していない と思われた。一方, 7つの島（銭洲, 鹳灘波島, 青ヶ島, ベョネーズ列岩, 明神礁, スミス島, 孀婦岩）では調査がおこなわれていない。個体群は鵜渡根島と三本岳の間，伊豆諸島北部を分 布の中心としている。かつて伊豆諸島は本種の最あ主要な繁殖地であると思われたが，20世紀 半ば以降, 個体群はつぎのような点から大きく減少してしまったと見ることができる。a) 式根 島や神津島ではすでに繁殖していないこと。b) 三本岳ではいくつかの営巣環境が失われている こよ。c)20世紀初頭において鵜渡根島や早島, 三本岳における卵採集者によって伝えられたよ うな大規模な営巣はもはや認められないこと。d) 大島〜新島間のフェリ一航路からの観察で, カンムリウミスズメは 1983〜89 年と比べて，1990９5 年には出現頻度がより低下したこと。 現在, 伊豆諸島では計 350-850つがいが繁殖していると思われる（カンムリウミスズメ全体の 推定個体数 4,000 10,000 羽，あるいは 2,000 5,000 つがいのうちの 7 43\% に相当）。そのう ち主要な繁殖地は祇苗島 $(100 \sim 300$ つがい), 恩馳島 (75〜150つがい), 三本岳 $(75 \sim 100$ つが い), そして小池根 (20 30つがい) である。最近の推定はないものの，このほかに，100３00 つがいがその他の島々（鵜渡根島, 新島, 早島, 鳥島) で営巣しているものと思われる。保全 上の問題はつぎのことがあげられる。人間の居住, 過去におこなわれた卵の採取, 離礁でのレ クリエーションフィッシング (磯釣り), 移入動物による捕食, 三本岳における爆撃演習による 繁殖場所消失, 人間活動による繁殖地の破壊, 火山噴火による営巣環境の消失, カラス類やへ ビ，八ヤブサによる相対的に高レベルでの捕食, そして刺し網漁業による死亡である。カンム リウミスズメは日本周辺に分布が限られており，ウミスズメ類のなかではもっとも希少である 
ことから，伊豆諸島においてはさらなる調査やモニタリング，そして保全上の問題に対する評 価をおこなっていくことが急務である。

ハリー・R.・カーター: Humboldt State University, Department of Wildlife, Arcata, CA 95521 USA. (Send correspondence: c/o U.S. Geological Survey, 6924 Tremont Road, Dixon, CA 95620 USA). E-mail: harry_carter@usgs.gov

小野宏治：北海道海鳥センター. $=$ T078-4116 北海道苫前郡羽幌町北 6 条 1 丁目. E-mail: ono@seabird.go.jp

ジョン・N.・フリーズ: University of California, Graduate Group in Ecology, Davis, CA 95616

USA. E-mail: jnfries@yahoo.com

長谷川 博：東邦大学動物生態学研究室. ₹274-8510 千葉県船橋市三山 2-2-1.

E-mail: hasegawa@bio.sci.toho-u.ac.jp

植田睦之：日本野鳥の会研究センター。テ191-0041 東京都日野市南平 2-35-2.

E-mail:mj-ueta@netlaputa.ne.jp

樋口広芳：東京大学院農学生命科学研究科. $=113-8657$ 東京都文京区弥生 1-1-1.

E-mail: higuchi@uf.a.u-tokyo.ac.jp

ジャック・T.・モイヤー: Miyakejima Nature Center (Akakokko-kan), 4188 Tsubota, Miyakemura, Miyakejima, Tokyo 100-1211 JAPAN

リー・オチクボ チャン: East Bay Municipal Utility District, 1 Winemasters Way, Lodi, CA 95240 USA. E-mail: lchan@ebmud.com

リー・N.・デ フォレスト: Parks Canada, 25 Eddy Street, Hull, Quebec K1A 0M5 CANADA. E-mail: Leah_de_Forest@pch.gc.ca

長谷川雅美：東邦大学地理生態学研究室. T274-8510 千葉県船橋市三山 2-2-1.

E-mail: mhase@bio.sci.toho-u.ac.jp

グスタフ・B.・バン ブリット：11P.O. Box 210442, Auke Bay, AK 99821 USA

Gus_vanVliet@envircon.state.ak.us 


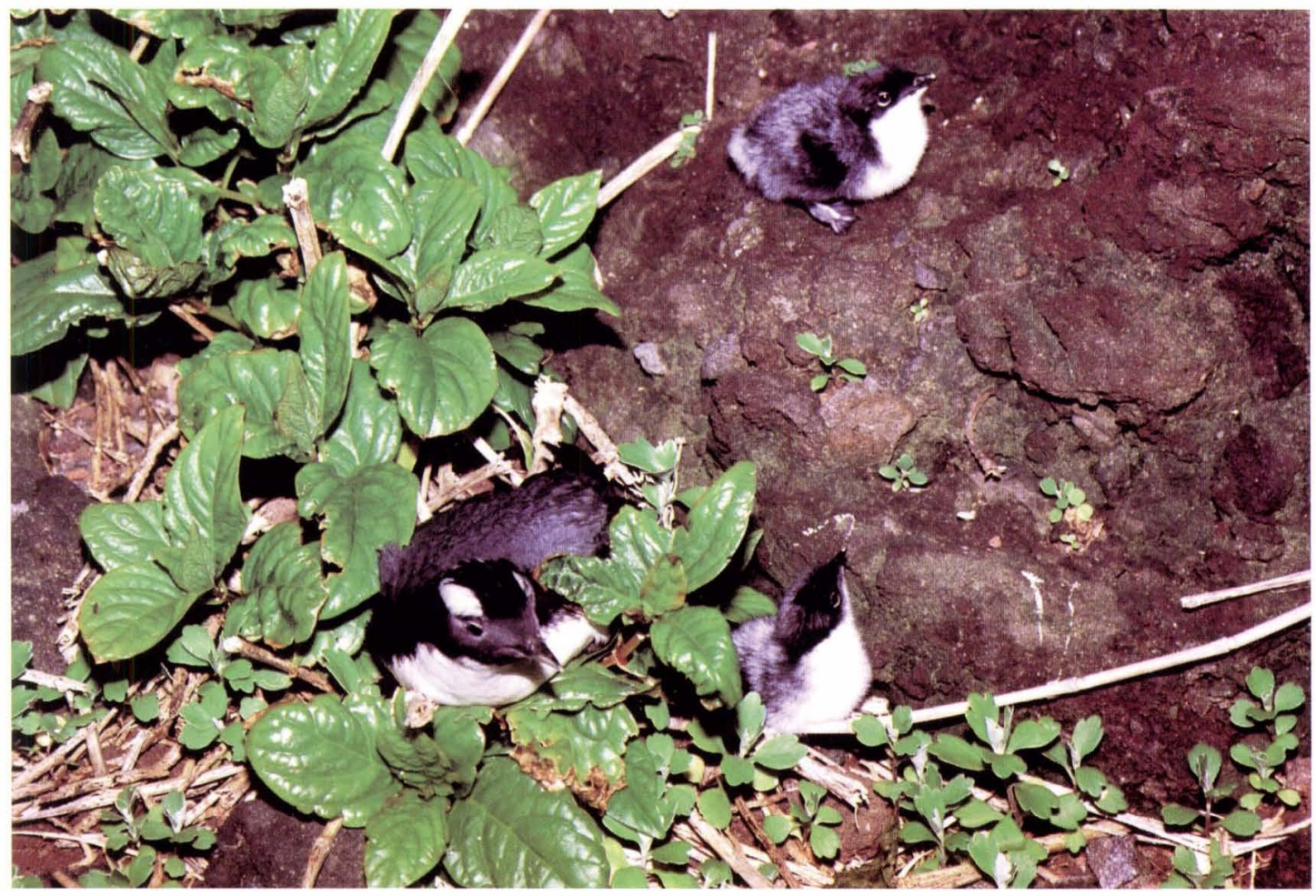

Family departure of Japanese Murrelets (Synthliboramphus wumizusume) at Kojine Islet, in May 1992 (photo by K. Ono). カンムリウミスズメの巣立ち。八丈小島小池根にて1992年5月に撮影。(小野宏治)

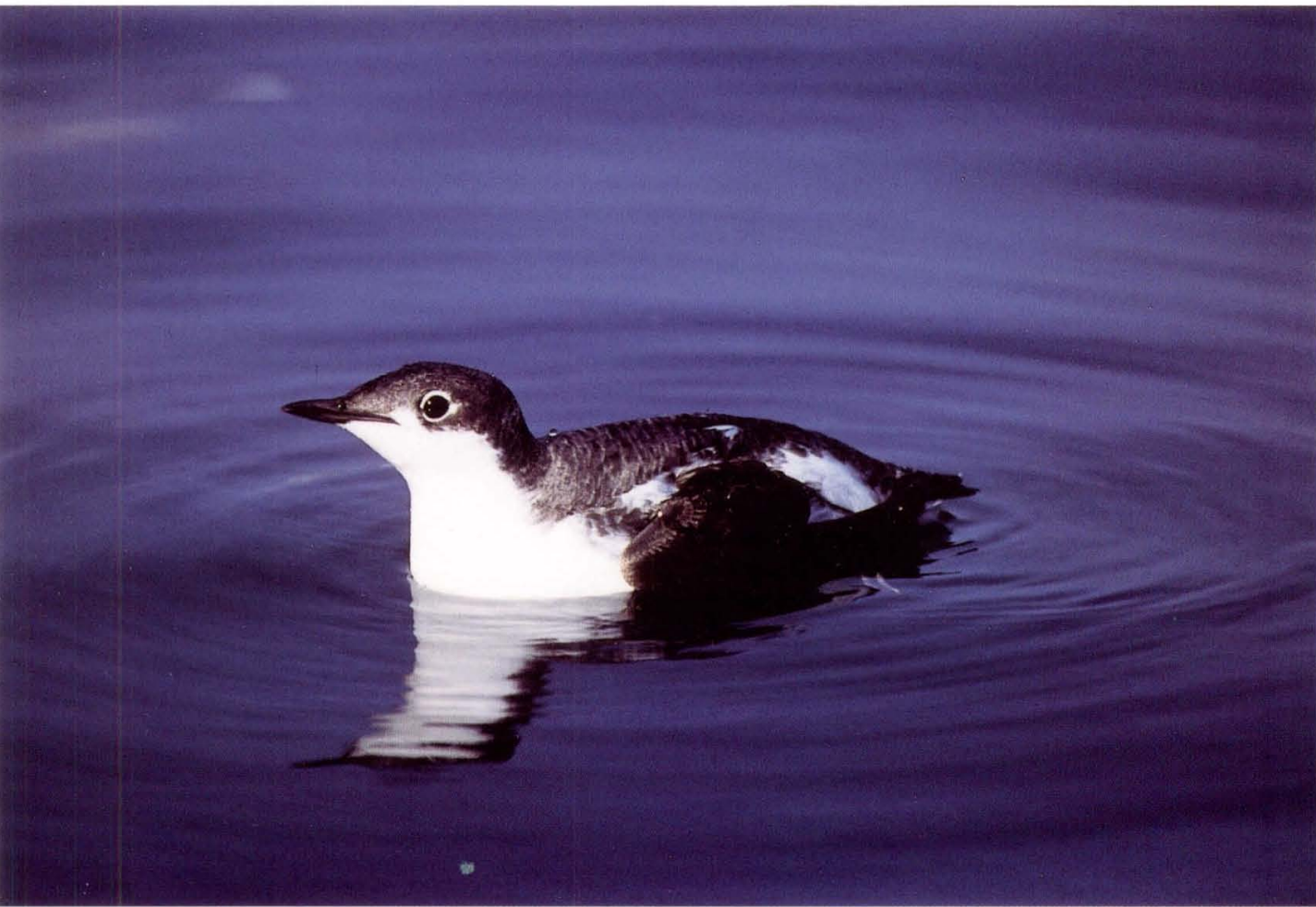

A Long-billed Murrelet (Brachyramphus perdix) wintering in Uchiura, Numazu, Shizuoka, Japan, on 3 Dec. 2000 (photo by J. Watanabe). 越冬中のハシナガウミスズメ。静岡県沼津市内浦にて2000年12月3日に撮影。(渡辺潤一)

注記：種名はアメリカ鳥学会の分類に従った。日本ではマダラウミスズメ Marbled Murrelet の栜種

(Brachyramphus marmoratus perdix) に位置づけられている. 